\title{
Electrochemical Evaluation of Constituent Intermetallics in Aluminum Alloy 2024-T3 Exposed to Aqueous Vanadate Inhibitors
}

\author{
K. D. Ralston, ${ }^{\mathrm{a}, *, \mathrm{z}}$ T. L. Young, ${ }^{\mathrm{b}}$ and R. G. Buchheit ${ }^{\mathrm{a}, * *}$ \\ ${ }^{a}$ Fontana Corrosion Center, Department of Materials Science and Engineering and ${ }^{b}$ Department \\ of Chemistry, The Ohio State University, Columbus, Ohio 43210, USA
}

\begin{abstract}
Experiments were conducted to determine how inhibiting forms of vanadate interact with complex Al alloy microconstituent intermetallics to impart corrosion protection. Cathodic polarization experiments on $\mathrm{Al}$ 2024-T3 indicate a strong correlation between inhibition and the presence of tetrahedrally coordinated vanadate. Anodic and cathodic polarization curves were measured on bulk synthesized $\mathrm{Al}_{2} \mathrm{Cu}, \mathrm{Al}_{2} \mathrm{CuMg}, \mathrm{Al}_{7} \mathrm{Cu}_{2} \mathrm{Fe}$, and $\mathrm{Al}_{20} \mathrm{Cu}_{2} \mathrm{Mn}_{3}$ in alkaline $0.5 \mathrm{M} \mathrm{NaCl}$ solutions with and without $10 \mathrm{mM}$ $\mathrm{NaVO}_{3}$. Vanadate additions generally decreased $E_{\text {corr }}$, increased $E_{\text {pit }}$, and decreased the cathodic kinetics of all tested materials. Because of decreased cathodic kinetics, open-circuit potentials (OCPs) were shifted in the active direction in aerated solutions when vanadate was present. This shift pins the OCP just below the observed pitting potential for $\mathrm{Al}_{2} \mathrm{CuMg}$ in vanadate solution, effectively preventing breakdown and subsequent support of rapid oxygen reduction by Cu-enriched clusters. $E_{\text {corr }}, E_{\text {pit }}, E_{\text {rp }}, i_{\text {corr }}$, $i_{\text {pass }}$, and $i$ at $-1.3 \mathrm{~V}_{\mathrm{SCE}}$ data from polarization experiments were summarized in cumulative distribution plots, and averages are presented in tabulated format. Scanning electron microscopy images of Al 2024-T3 used for $4 \mathrm{~h}$ of OCP measurement show that vanadate greatly decreased circumferential trenching around intermetallic particles in both aerated and deaerated solutions. Potentiostatic hold experiments were used to show suppression of $\mathrm{Al}_{2} \mathrm{CuMg}$ dissolution in vanadate solutions (c) 2009 The Electrochemical Society. [DOI: 10.1149/1.3076147] All rights reserved.
\end{abstract}

Manuscript submitted October 6, 2008; revised manuscript received January 5, 2009. Published February 9, 2009.

Aluminum 2024-T3 is a high-strength age-hardened aluminum alloy commonly used in the aerospace industry. Al 2024-T3 contains, by weight percent, $3.8-4.9 \mathrm{Cu}, 1.2-1.8 \mathrm{Mg}, 0.3-0.9 \mathrm{Mn}$, and small quantities of $\mathrm{Si}, \mathrm{Fe}, \mathrm{Zn}, \mathrm{Cr}$, and $\mathrm{Ti}^{1}{ }^{1}$ Alloy additions result in both superior mechanical properties and a heterogeneous microstructure which renders the alloy susceptible to localized corrosion. ${ }^{1}$ Appreciable quantities of copper, magnesium, and manganese, added as strengtheners, remain in solid solution. However, through heat-treatments and natural aging, a dispersion of fine $\mathrm{Cu}$ and $\mathrm{Mg}$ particles and insoluble intermetallic precipitates form within the matrix phase. The main constituent particles in $\mathrm{Al}$ 2024-T3 include $\mathrm{Al}_{2} \mathrm{CuMg}, \mathrm{Al}_{7} \mathrm{Cu}_{2} \mathrm{Fe}, \mathrm{Al}_{2} \mathrm{Cu}$, and $\mathrm{Al}_{20} \mathrm{Cu}_{2} \mathrm{Mn}_{3}$. The effect of intermetallic particles on corrosion of aluminum alloys has been widely studied. ${ }^{2-11}$ For Al 2024-T3, it has been found that intermetallics containing $\mathrm{Cu}$ are typically noble or become noble to the surrounding aluminum matrix during exposure to many electrolytes, and these particles are capable of supporting rapid cathodic kinetics. ${ }^{4,5,8,9,12}$ Such cathodic particles drive corrosion in the surrounding matrix, leading to pitting and trenching attack morphologies. ${ }^{10,11,13} \mathrm{Al}_{2} \mathrm{CuMg}$ (S phase) intermetallic particles are of particular interest, because $\mathrm{Al}_{2} \mathrm{CuMg}$ is one of the most abundant intermetallic particles found in $\mathrm{Al} 2024-\mathrm{T} 3$ and in large part has been found to be responsible for susceptibility of Al 2024-T3 to localized corrosion. ${ }^{4,5}$ The corrosion of $\mathrm{Al}_{2} \mathrm{CuMg}$ is complex; under free-corrosion conditions, the intermetallic is initially anodically polarized by the matrix, leading to selective dissolution of $\mathrm{Mg}$ from the intermetallic and nonfaradaic liberation of $\mathrm{Cu}$, which can then be oxidized to form ions that can be reduced on the surrounding matrix. ${ }^{4,5}$ Often what remains of the particle is an enriched $\mathrm{Cu}$ remnant, which acts as a local cathode, supporting rapid oxygen reduction and corrosion in the surrounding matrix. ${ }^{4,5}$ Prevention of $\mathrm{Mg}$ dissolution from $\mathrm{Al}_{2} \mathrm{CuMg}$ and, as a result, the subsequent formation of local $\mathrm{Cu}$ cathodes capable of supporting rapid oxygen reduction could be an effective way to increase the resistance of $\mathrm{Al}$ 2024-T3 to localized corrosion. ${ }^{14}$

Historically, chromate-based pigments and coatings have been used successfully to prevent corrosion of aluminum alloys. ${ }^{15}$ However, due to environmental and carcinogenic risks associated with chromate use, more "green" alternative inhibitors and coatings have

\footnotetext{
* Electrochemical Society Student Member.

** Electrochemical Society Active Member.

z E-mail: ralston.34@osu.edu
}

recently received attention. In particular, soluble vanadates, vanadate-based coatings, and inhibitor pigments have been observed to inhibit the corrosion of aluminum alloys and have shown promise as chromate replacements. ${ }^{16-23}$ However, unlike chromates, aqueous vanadates have a relatively complex aqueous chemistry, dependent on $\mathrm{pH}$, concentration, and ionic strength. ${ }^{24-26}$ This convolutes a straight forward understanding of inhibition. In a simplified description of aqueous vanadate speciation, tetrahedrally coordinated species, metavanadates, and pyrovanadates, predominate in alkaline solutions, octahedrally coordinated species, decavanadates, predominate in acid solutions, and single tetrahedral species exist over a wide $\mathrm{pH}$ range at low concentrations. Previous work has shown that the extent of inhibition depends strongly on vanadate speciation, with the greatest inhibition from tetrahedrally coordinated species, which are predominant in alkaline solutions. ${ }^{18,20-22,27}$ Tetrahedrally coordinated vanadates have been shown to act primarily through decreased oxygen reduction; however, vanadates have also been observed to be modest anodic inhibitors independent of aeration. ${ }^{18,22}$ Decavanadate ions, which are combinations of $10 \mathrm{oc}-$ tahedrally coordinated vanadate units, are predominate in acidic solutions of appropriate vanadium concentration and have been shown to be poor inhibitors of oxygen reduction. ${ }^{18,20-22,24,25,27}$ There is evidence that decavanadate increases the cathodic kinetics in acidic $\mathrm{NaCl}$ solutions. ${ }^{18}$ However, small increases in $\mathrm{pH}$, as found near sites supporting oxygen reduction, can trigger the decomposition of noninhibiting octahedrally coordinated species into inhibiting tetrahedral species, which helps explain corrosion protection observed from pigments containing decavanadate. ${ }^{16,18,28,29}$

Evidence exists that inhibiting tetrahedrally coordinated vanadates suppress the dissolution of $\mathrm{Al}_{2} \mathrm{CuMg}$ intermetallics. ${ }^{18,21,27}$ Ralston et al. noted suppressed $\mathrm{Mg}$ dissolution from $\mathrm{Cu}-\mathrm{Mg}$ particles exposed to alkaline and mildly acidic $50 \mathrm{mM} \mathrm{NaCl}$ solutions with $\mathrm{NaVO}_{3}$ compared to particles exposed to $\mathrm{NaVO}_{3}$-free solutions. ${ }^{18}$ Iannuzzi and Frankel used in situ atomic force microscopy scratching to observe that additions as small as $0.1 \mathrm{mM}$ of metavanadate to $0.5 \mathrm{M} \mathrm{NaCl}$ suppressed the attack of $\mathrm{Al}_{2} \mathrm{CuMg}$ particles, while corrosion in the surrounding matrix was still observed. ${ }^{27}$ Iannuzzi further found that $5 \mathrm{mM}$ of metavanadate prevented transient $\mathrm{Al}_{2} \mathrm{CuMg}$ dissolution, resulting in increased corrosion resistance at open-circuit potential (OCP) ${ }^{20,21}$ The mechanism of suppression of transient dissolution was not clear, but it was speculated that monovanadates on the matrix prevent or displace $\mathrm{Cl}^{-}$ adsorption on the surface, which hinders subsequent oxide film breakdown. ${ }^{20}$ Generally, it is not certain whether vanadates slow 
corrosion of $\mathrm{Al}$ 2024-T3 through acting exclusively on $\mathrm{Al}_{2} \mathrm{CuMg}$ or if suppressed $\mathrm{Al}_{2} \mathrm{CuMg}$ dissolution is a consequence of overall corrosion inhibition. Although previous work has established that solutions containing predominately tetrahedrally coordinated vanadates prevent or slow $\mathrm{Mg}$ dissolution from $\mathrm{Al}_{2} \mathrm{CuMg}$, and in turn the formation of $\mathrm{Cu}$-rich cathodes capable of supporting rapid oxygen reduction, the precise relationship between tetrahedral vanadates, $\mathrm{Al}_{2} \mathrm{CuMg}$, and the matrix is not currently understood.

Vanadate is a known buffer, and observed inhibition must be rationalized in the context of the effects that buffers have on corrosion. The presence of a buffer can have pronounced effects on the corrosion of $\mathrm{Al}-\mathrm{Cu}$ alloys. ${ }^{30,31}$ In unbuffered systems, oxygen reduction results in an increase in alkalinity at cathodic sites, which dissolves the surrounding $\mathrm{Al}$ matrix, leading to shallow grooving and trenching around intermetallics and, occasionally, widespread cathodic corrosion across the matrix. ${ }^{30,31}$ When a buffer is present, local alkalinization and associated cathodic corrosion damage modes are suppressed. However, when these modes are suppressed, the cathodic reaction is then available to support penetrating localized corrosion sites such as acid pits and crevices. ${ }^{30,31}$ This leads to deep and discrete pits but comparatively less mass loss than is observed in unbuffered systems. ${ }^{30}$

Due to the small size of constituent intermetallic particles present in Al 2024-T3, direct electrochemical testing of different intermetallics in the matrix is not feasible. However, previous work on aluminum alloys using a microcapillary electrode and synthesized "bulk" intermetallics demonstrates that intermetallic-specific electrochemical data can be obtained. ${ }^{2,3,32}$ The microcell is a modified standard three-electrode setup that uses a thin, glass, silicon-coated capillary connected to an electrolyte reservoir, containing both a reference electrode and counter electrode to contact and allow electrochemical experiments on micrometer-scale-diameter working electrodes. ${ }^{33,34}$ General details of the microcell setup and a specific description of the microcell used for this work can be found in the literature. ${ }^{3,33,34}$ By choosing bulk intermetallics that are representative of constituents in $\mathrm{Al} 2024-\mathrm{T} 3$, pure $\mathrm{Al}$ and $\mathrm{Cu}$, and an $\mathrm{Al} 4 \% \mathrm{Cu}$ solid solution used as a matrix analog, electrochemical characteristics of specific intermetallic phases can be catalogued and used to rationalize observed behavior of the bulk alloy.

The objective of this work is to determine how inhibiting vanadates interact with the matrix and constituent particles of Al 2024T3. In addition, this work aims to develop a deeper understanding of the suppression of $\mathrm{Mg}$ dissolution from $\mathrm{Al}_{2} \mathrm{CuMg}$ intermetallics in inhibiting vanadate solutions.

\section{Experimental}

Solution preparation.- Solutions for all experiments were prepared using reagent-grade chemicals. The $\mathrm{NaVO}_{3}$ for solution preparation was purchased from Fluka Chemika with an assay of $\geqslant 98 \%$. Cathodic polarization experiments were conducted in $0.5 \mathrm{M}$ $\mathrm{NaCl}$ solutions adjusted to $\mathrm{pH} 5.1$ using $\mathrm{HCl}$ with 0.25 and $0.0025 \mathrm{M} \mathrm{NaVO}_{3}$ to show the effect that tetrahedral vanadates have on inhibition compared to octahedral vanadates. However, most experiments were conducted in alkaline $0.5 \mathrm{M} \mathrm{NaCl}$ solutions with and without $10 \mathrm{mM} \mathrm{NaVO}_{3}$ to characterize the inhibitive effect tetrahedrally coordinated vanadates have on different constituent inter-

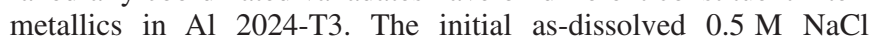
$+10 \mathrm{mM} \mathrm{NaVO}$ solution was yellow and had a $\mathrm{pH}$ of 6.37 . As previously mentioned, vanadates have been shown to provide the strongest inhibition when coordinated tetrahedrally, which occurs in alkaline solutions. As a result, the $\mathrm{pH}$ of the master test solution was adjusted with dropwise additions of $10 \mathrm{~N} \mathrm{NaOH}$ until the $\mathrm{pH}$ reached 9.18. Before experimentation, the test solution was allowed to equilibrate for more than 2 weeks, during which a few additional drops of $\mathrm{NaOH}$ were used to maintain the $\mathrm{pH}$ above 9 . Once the $\mathrm{pH}$ was stable, nuclear magnetic resonance (NMR) was used to characterize the solution. To help ensure that the vanadate species in solution were not evolving with time, the solution $\mathrm{pH}$ was monitored daily over the course of microcell experimentation, and NMR spectra were collected prior to the first experiment and after completion of the last experiment. The same $0.5 \mathrm{M} \mathrm{NaCl}+10 \mathrm{mM} \mathrm{NaVO}_{3}$ solution was used for subsequent experiments after completion of the microcell polarization work. Because the solution appeared stable over the duration of microcell experiments, $\mathrm{pH}$ was used as a sufficient measure of solution and species stability. Although the $\mathrm{NaVO}_{3}$ solution remained stable, the $\mathrm{pH}$ of $\mathrm{NaCl}$ solutions adjusted to approximately $\mathrm{pH} 9.2$ decreased with time. This is likely the result of $\mathrm{H}_{2} \mathrm{CO}_{3}$ formation from dissolved atmospheric $\mathrm{CO}_{2}$ and the subsequent proton formation from equilibria involving $\mathrm{HCO}_{3}^{-}$and $\mathrm{CO}_{3}^{2-}$, which both have increased solubility in alkaline solutions. ${ }^{35}$ As a result, care was taken to monitor and measure the $\mathrm{pH}$ immediately prior to and during each testing session. Unless specifically stated, the $\mathrm{pH}$ of $\mathrm{NaCl}$-only solutions was between 9.05 and 9.20. Additionally, the reservoir, capillary, and tubing of the microcell were frequently flushed with fresh solution throughout experimentation.

NMR. - Vanadates have a complex aqueous speciation depending on both concentration and $\mathrm{pH}$, and as a result, small changes in $\mathrm{pH}$ can have dramatic effects on the type and concentration of specific species in solution. NMR was used to characterize solutions used for cathodic polarization experiments on an Al 2024-T3 sheet in $\mathrm{pH} 5.1 \mathrm{NaVO}_{3}$ solutions and microcell polarization experiments in alkaline $10 \mathrm{mM} \mathrm{NaVO}_{3}$ solution, which were expected to take a number of weeks to complete and for which the possibility of solution evolution with time was a concern. After allowing approximately 2 weeks for solution stabilization, NMR spectra were collected immediately prior to microcell work in vanadate solutions and 10 days later after completion of experimentation. NMR spectra for cathodic polarization experiments in $\mathrm{pH} 5.1$ solutions were collected immediately after the $\mathrm{pH}$ of the vanadate solutions was adjusted. A Bruker DPX $400 \mathrm{MHz}$ superconducting magnet was used to collect high-resolution ${ }^{51} \mathrm{~V}(105.2 \mathrm{MHz}) \mathrm{NMR}$ spectra. An indirect detection probe was used with a $90^{\circ}$ pulse duration of $10.38 \mu \mathrm{s}$. Spectra were collected using 8192 transients, a spectral window of $73,529 \mathrm{~Hz}$, a $0.051 \mathrm{~s}$ acquisition time, and a $0.20 \mathrm{~s}$ relaxation delay. Each spectrum had the subsequent process parameters applied: $10.0 \mathrm{~Hz}$ line broadening, zero filling ( $25 \mathrm{~K}$ points), and baseline correction. A solution consisting of $20 \% \mathrm{v} / \mathrm{v} \mathrm{VOCl}_{3}$ in $\mathrm{C}_{6} \mathrm{D}_{6}$ $\left(\delta^{51} \mathrm{~V}=0 \mathrm{ppm}\right)$ was used as an external standard to reference the ${ }^{51} \mathrm{~V}$ chemical shifts. Peaks were identified by comparison to literature. $^{26,29,36}$

Potentiodynamic polarization using the microcapillary electrode.- To characterize the inhibitive effects of tetrahedrally coordinated vanadates, anodic and cathodic polarization curves were collected on representative bulk versions of intermetallics found in Al 2024-T3 in alkaline $10 \mathrm{mM} \mathrm{NaVO}+0.5 \mathrm{M} \mathrm{NaCl}$ and $\mathrm{NaVO}_{3}$-free $0.5 \mathrm{M} \mathrm{NaCl}$ solutions. Samples used for potentiodynamic polarization experiments using the microcell were sourced from previous work and commercial suppliers. The $99.999 \% \mathrm{Al}$ and 99.9\% $\mathrm{Cu}$ samples were obtained from Alfa Aesar. The intermetallic samples used in this study were prepared and studied previously: $\mathrm{Al}_{7} \mathrm{Cu}_{2} \mathrm{Fe}$ and $\mathrm{Al}_{20} \mathrm{Cu}_{2} \mathrm{Mn},{ }^{32} \mathrm{Al} 4 \% \mathrm{Cu},{ }^{3} \mathrm{Al}_{2} \mathrm{CuMg},{ }^{4}$ and $\mathrm{Al}_{2} \mathrm{Cu} .{ }^{37}$ Samples were ground in 200 proof ethyl alcohol to $1 \mu \mathrm{m}$ using $\mathrm{SiC}$ grinding papers, followed by polishing using 6 and $1 \mu \mathrm{m}$ diamond pastes. All electrochemical experiments presented in this paper were made using an Autolab PGSTAT 100 potentiostat in conjunction with General Purpose Electrochemical Systems data-acquisition software. Both anodic and cathodic polarization experiments were preceded by $30 \mathrm{~s}$ of OCP measurement and were carried out in aerated solutions using a $0.01 \mathrm{~V} / \mathrm{s}$ scan rate. Anodic polarization curves were initiated at $-0.03 \mathrm{~V}$ vs OCP and reversed at either $0.0 \mathrm{~V}$ vs OCP or manually at approximately $0.05 \mathrm{~V}$ above any observed breakdown. Cathodic polarization experiments were initiated at $0.03 \mathrm{~V}$ vs OCP and terminated at $-2.0 \mathrm{~V}$ vs saturated calomel electrode (SCE), although capillary tip leaking often resulted in 
early termination of the experiment. The contact area used for area normalization of data was estimated from digital images taken after individual experiments.

Electrochemical experiments on bulk Al2024-T3 sheet.- Experiments on bulk Al 2024-T3 electrodes in alkaline $0.5 \mathrm{M} \mathrm{NaCl}$ solutions with and without $10 \mathrm{mM} \mathrm{NaVO}$ were used to obtain electrochemical data from the actual alloy for comparison to microcell results. Experiments in $\mathrm{pH} 5.1 \mathrm{NaVO}_{3}$ solutions were used to show the inhibiting effect that tetrahedrally coordinated vanadates have on cathodic kinetics compared to octahedrally coordinated vanadates. Further, work on bulk Al 2024-T3 was used to gain insight into $\mathrm{Al}_{2} \mathrm{CuMg}$ dissolution. An $\mathrm{Al} 2024-\mathrm{T} 3$ sheet was used for four different sets of experiments, cathodic polarization, OCP measurement, anodic polarization, and potentiostatic experiments. All samples were polished by hand in 200 proof ethyl alcohol to at least $1 \mu \mathrm{m}$ in a similar fashion as discussed for microcell sample preparation except for the samples for OCP measurements, which were polished to $1 / 4 \mu \mathrm{m}$ using diamond paste, the samples for potentiostatic experiments, which were polished to $1 \mu \mathrm{m}$ using a diamond suspension, and an automatic polisher rather than diamond paste by hand, and the samples used for cathodic polarization, which were polished to 1200 grit under ethyl alcohol. Experiments on a bulk Al 2024-T3 sheet were carried out using a standard three-electrode setup, which included a SCE reference, a platinum counter electrode mesh, and $1 \mathrm{~cm}^{2}$ exposed working electrode. Cathodic polarization experiments in actively aerated $\mathrm{pH} 5.1 \mathrm{NaVO}_{3}$ solutions were preceded by a 30 min measurement of OCP. The scan was initiated at $0.03 \mathrm{~V}$ vs $\mathrm{OCP}$, and a scan rate of $0.5 \mathrm{mV} / \mathrm{s}$ was used. OCP was measured for $4 \mathrm{~h}$ in actively aerated and deaerated $0.5 \mathrm{M} \mathrm{NaCl}$ solutions at approximately $\mathrm{pH} 9.2$ with and without $10 \mathrm{mM} \mathrm{NaVO}_{3}$ to determine the effect of tetrahedrally coordinated vanadates on OCP with time. For deaerated OCP measurements, solutions were deaerated for $1 \mathrm{~h}$ before the electrolyte came in contact with the sample. Anodic polarization curves on the $\mathrm{Al} 2024-\mathrm{T} 3$ sheet in $0.5 \mathrm{M} \mathrm{NaCl}$ solution with $10 \mathrm{mM} \mathrm{NaVO}_{3}$ solution at approximately $\mathrm{pH} 9.17$ were used to make comparisons between microcell data and data collected from the Al 2024-T3 sheet. Anodic polarization experiments were preceded by a $30 \mathrm{~min}$ measurement of OCP. The scan was initiated at $-0.03 \mathrm{~V}$ vs OCP, and a scan rate of $0.5 \mathrm{mV} / \mathrm{s}$ was used with scan reversal at $-0.25 \mathrm{~V}_{\mathrm{SCE}}$. Potentiostatic hold experiments were conducted in $0.5 \mathrm{M} \mathrm{NaCl}$ solutions between $\mathrm{pH} 9.1$ and 9.23 with and without $10 \mathrm{mM} \mathrm{NaVO}_{3}$. These experiments were used to determine if tetrahedral vanadates have an effect on the repassivation of the surface once activated and to show the suppression of $\mathrm{Mg}$ dissolution from $\mathrm{Al}_{2} \mathrm{CuMg}$ intermetallics. Each $100 \mathrm{~mL}$ test solution was deaerated for $30 \mathrm{~min}$ prior to experimentation and sample exposure. The samples were held at a conditioning potential of $1 \mathrm{~V}_{\mathrm{SCE}}$ for $1 \mathrm{~s}$ and then held at a specific potential for the next $120 \mathrm{~s}$; potential holds at $-1.2,-0.9,-0.8,-0.7,-0.6$, and $-0.5 \mathrm{~V}_{\mathrm{SCE}}$ were used.

\section{Results}

Inhibition from tetrahedral vanadate species vs octahedral species.- The effect that tetrahedrally coordinated vanadates have on cathodic kinetics compared to octahedrally coordinated species can be observed through experiments in mildly acidic $\mathrm{NaVO}_{3}$ solutions. Figure 1 shows the NMR spectra from two different $\mathrm{pH} 5.10 .5 \mathrm{M}$ $\mathrm{NaCl}$ solutions with (a) 0.0025 and (b) $0.25 \mathrm{M} \mathrm{NaVO}_{3}$. The subscript of the peak labels in the figure describes the number of vanadium atoms in each oligomer. For example, $\mathrm{V}_{1}$ indicates single tetrahedrally coordinated vanadium $\left[\mathrm{VO}_{4}^{3-}, \mathrm{VO}_{3}(\mathrm{OH})^{2-}, \mathrm{VO}_{2}(\mathrm{OH})_{2}^{-}\right.$, $\left.\mathrm{VO}(\mathrm{OH})_{3}\right], \mathrm{V}_{2}$ indicates dimeric vanadate $\left[\mathrm{V}_{2} \mathrm{O}_{7}^{4-}, \mathrm{V}_{2} \mathrm{O}_{6}(\mathrm{OH})^{3-}\right]$, $\mathrm{V}_{4}$ is tetrameric $\left(\mathrm{V}_{4} \mathrm{O}_{12}^{4-}, \mathrm{V}_{4} \mathrm{O}_{13}^{6-}\right), \mathrm{V}_{5}$ is pentameric $\left(\mathrm{V}_{5} \mathrm{O}_{16}^{7-}, \mathrm{V}_{5} \mathrm{O}_{15}^{5-}\right)$, and $\mathrm{V}_{10}$ represents decameric vanadate species $\left[\mathrm{V}_{10} \mathrm{O}_{28}^{6-}\right.$, $\left.\mathrm{V}_{10} \mathrm{O}_{26}(\mathrm{OH})_{2}^{4-}, \mathrm{V}_{10} \mathrm{O}_{27}(\mathrm{OH})^{5-}\right]^{25,26,29,36} \mathrm{~V}_{1}, \mathrm{~V}_{2}, \mathrm{~V}_{4}$, and $\mathrm{V}_{5}$ are tetrahedrally coordinated species, and $\mathrm{V}_{10}$ is octahedrally coordinated. Also, the vertical scales of the two spectra in Fig. 1 have been adjusted so that peaks in both spectra can be observed. As a result,
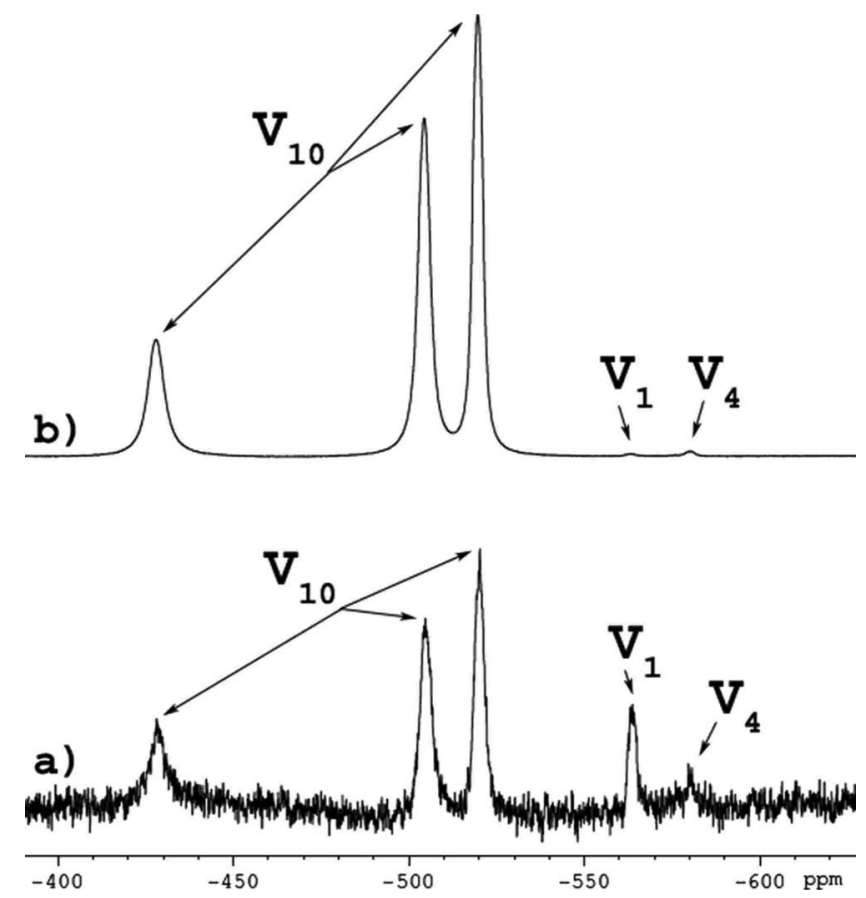

Figure 1. NMR spectra of pH 5.1 $0.5 \mathrm{M} \mathrm{NaCl}$ solutions with (a) 0.0025 and (b) $0.25 \mathrm{M} \mathrm{NaVO}_{3}$. The dilute $\mathrm{NaVO}_{3}$ solution has a greater proportion of tetrahedrally coordinated species $\left(\mathrm{V}_{1}\right.$ and $\left.\mathrm{V}_{4}\right)$ relative to octahedrally coordinated species $\left(\mathrm{V}_{10}\right)$ compared to the more-concentrated $\mathrm{NaVO}_{3}$ solution, which contains mostly octahedrally coordinated species.

the two spectra cannot be compared quantitatively. However, the data do show that the $0.0025 \mathrm{M} \mathrm{NaVO}_{3}$ solution has a greater proportion of tetrahedral species relative to octahedral species compared to the $0.25 \mathrm{M} \mathrm{NaVO}_{3}$ solution, which contains significantly more octahedral species than tetrahedral species.

Figure 2 shows cathodic polarization curves on Al 2024-T3 in aerated $\mathrm{pH} 5.10 .5 \mathrm{M} \mathrm{NaCl}$ with 0.25 and $0.0025 \mathrm{M} \mathrm{NaVO}_{3}$ and without $\mathrm{NaVO}_{3}$. These experiments show the inverse relationship between $\mathrm{NaVO}_{3}$ concentration and inhibition of cathodic kinetics at $\mathrm{pH}$ 5.1, where the dilute solutions containing relatively more tetrahedrally coordinated vanadate to octahedral vanadates have a larger reduction in cathodic kinetics than more-concentrated solutions with relatively more octahedrally coordinated decavanadate.

Tetrahedral vanadate species in alkaline electrolytes. - Small changes in solution $\mathrm{pH}$ can have a large effect on vanadate speciation. Concerns that the vanadate test solutions would change over the course of microcell experimentation, with consequences for inhibitor behavior, were addressed using NMR. Figure 3 shows the spectra from two samples of $\mathrm{pH} 9.170 .5 \mathrm{M} \mathrm{NaCl}+10 \mathrm{mM} \mathrm{NaVO}_{3}$ test solution taken immediately before microcell experimentation and 10 days later after the conclusion of experimentation in vanadate solutions. The solution did remain stable over the course of experimentation and was found to contain a number of different tetrahedral vanadate species as expected from previous work on vanadate inhibition. ${ }^{18,22}$ The assignments of $V_{4}$ and $V_{5}$ are not certain, as two different standards available in the literature leave room for speculative interpretation. ${ }^{26,36}$ However, definitive assignment of these species is not critical for this work. The solution used for this work contained tetrahedrally coordinated species and predominately $\mathrm{V}_{1}$; no octahedrally coordinated vanadates were detected.

Polarization of intermetallics in tetrahedral vanadate solutions. - Figures 4a-g show sample anodic polarization curves for pure $\mathrm{Al}$, pure $\mathrm{Cu}, \mathrm{Al} 4 \% \mathrm{Cu}, \mathrm{Al}_{2} \mathrm{Cu}, \mathrm{Al}_{2} \mathrm{CuMg}, \mathrm{Al}_{7} \mathrm{Cu}_{2} \mathrm{Fe}$, and $\mathrm{Al}_{20} \mathrm{Cu}_{2} \mathrm{Mn}_{3}$, respectively. The objective of these experiments was to determine the effect of tetrahedral vanadates on the anodic behav- 


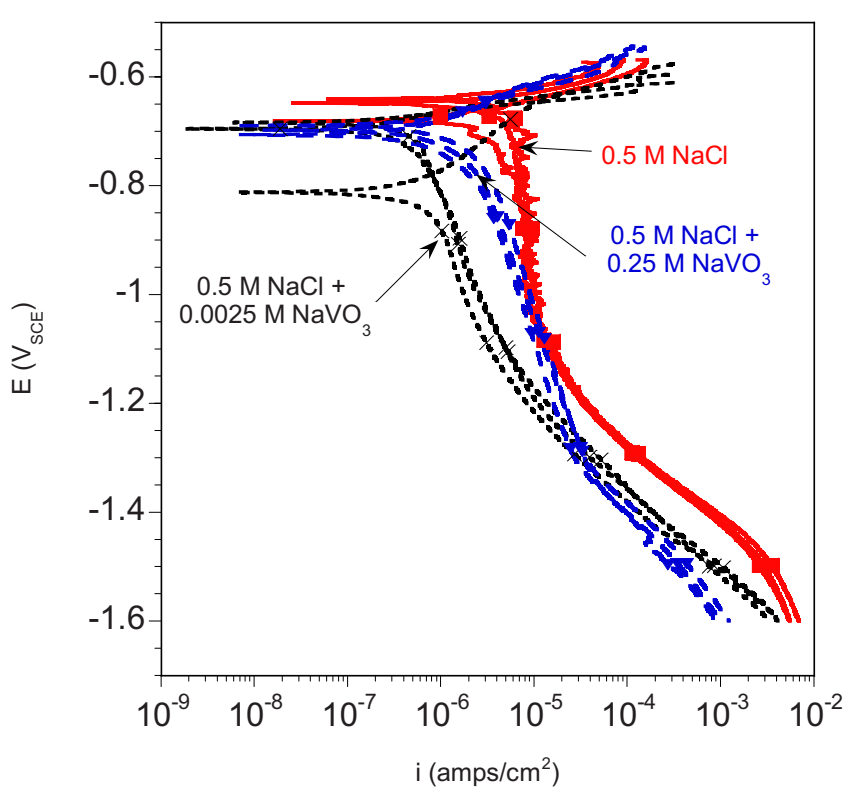

Figure 2. (Color online) Cathodic polarization curves on $\mathrm{Al}$ 2024-T3 in aerated $\mathrm{pH} 5.10 .5 \mathrm{M} \mathrm{NaCl}$ with 0.25 and $0.0025 \mathrm{M} \mathrm{NaVO}_{3}$ and without $\mathrm{NaVO}_{3}$. These experiments show an inverse relationship between $\mathrm{NaVO}_{3}$ concentration and inhibition of cathodic kinetics at $\mathrm{pH}$ 5.1, which correlates well with a transition from solutions dominated by octahedrally coordinated vanadates to tetrahedral vanadates.

ior of different constituent intermetallic particles in Al 2024-T3. Detailed anodic polarization results are discussed below in conjunction with cathodic polarization results for each intermetallic.

Figures 5a-g are a collection of cumulative distribution plots showing $E_{\text {corr }}, E_{\text {pit }}$, and $E_{\mathrm{rp}}$ for various intermetallic compounds. $E_{\text {corr }}$ is the corrosion potential, $E_{\text {pit }}$ is the pitting potential, and $E_{\mathrm{rp}}$ is the reversible potential on the reverse scan, which was defined as the potential at the smallest observed current on the reverse scan. $\mathrm{Cu}-$ mulative probability plots are of value because there can be significant variation in the measured characteristic potentials of intermetallic compounds. Knowing this variation is important in the interpretation of corrosion processes. The statistical variation, which would be lost by simply taking averages, can be shown fully in cumulative distribution plots. The corrosion rate was estimated from both anodic and cathodic polarization curves (to be presented later) by extrapolation of linear passive regions and regions of oxygen reduction, respectively, to the intersection with corrosion potential.

Figures 6a-g show sample cathodic polarization curves for pure $\mathrm{Al}$, pure $\mathrm{Cu}, \mathrm{Al} 4 \% \mathrm{Cu}, \mathrm{Al}_{2} \mathrm{Cu}, \mathrm{Al}_{2} \mathrm{CuMg}, \mathrm{Al}_{7} \mathrm{Cu}_{2} \mathrm{Fe}$, and $\mathrm{Al}_{20} \mathrm{Cu}_{2} \mathrm{Mn}_{3}$, respectively. These experiments were used to determine the effect of vanadates on cathodic kinetics of intermetallic particles in $\mathrm{Al}$ 2024-T3.

Figures $7 \mathrm{a}-\mathrm{g}$ are a collection of cumulative distribution plots showing corrosion current density $\left(i_{\text {corr }}\right)$, passivation current density $\left(i_{\text {pass }}\right)$, and current density at $-1.3 \mathrm{~V}_{\mathrm{SCE}}$ for tested intermetallics and metals. Passivation current density was defined as the current density immediately before breakdown. The current density at $-1.3 \mathrm{~V}_{\mathrm{SCE}}$ was used as a comparative measure of cathodic reduction kinetics, because the potential at this point was below the most active $E_{\text {corr }}$ and this point of the curve allowed a direct comparison of reduction kinetics at potentials where oxygen reduction reactions likely contributed to the cathodic response. Considerable hydrogen evolution reactions may also be present at $-1.3 \mathrm{~V}_{\mathrm{SCE}}$. The following presents results for each tested material.

Pure Al.- The addition of $10 \mathrm{mM} \mathrm{NaVO}$ to alkaline $0.5 \mathrm{M}$ $\mathrm{NaCl}$ results in a shift of corrosion potential to more active potentials relative to $\mathrm{NaVO}_{3}$-free solutions on pure Al. However, $\mathrm{NaVO}_{3}$
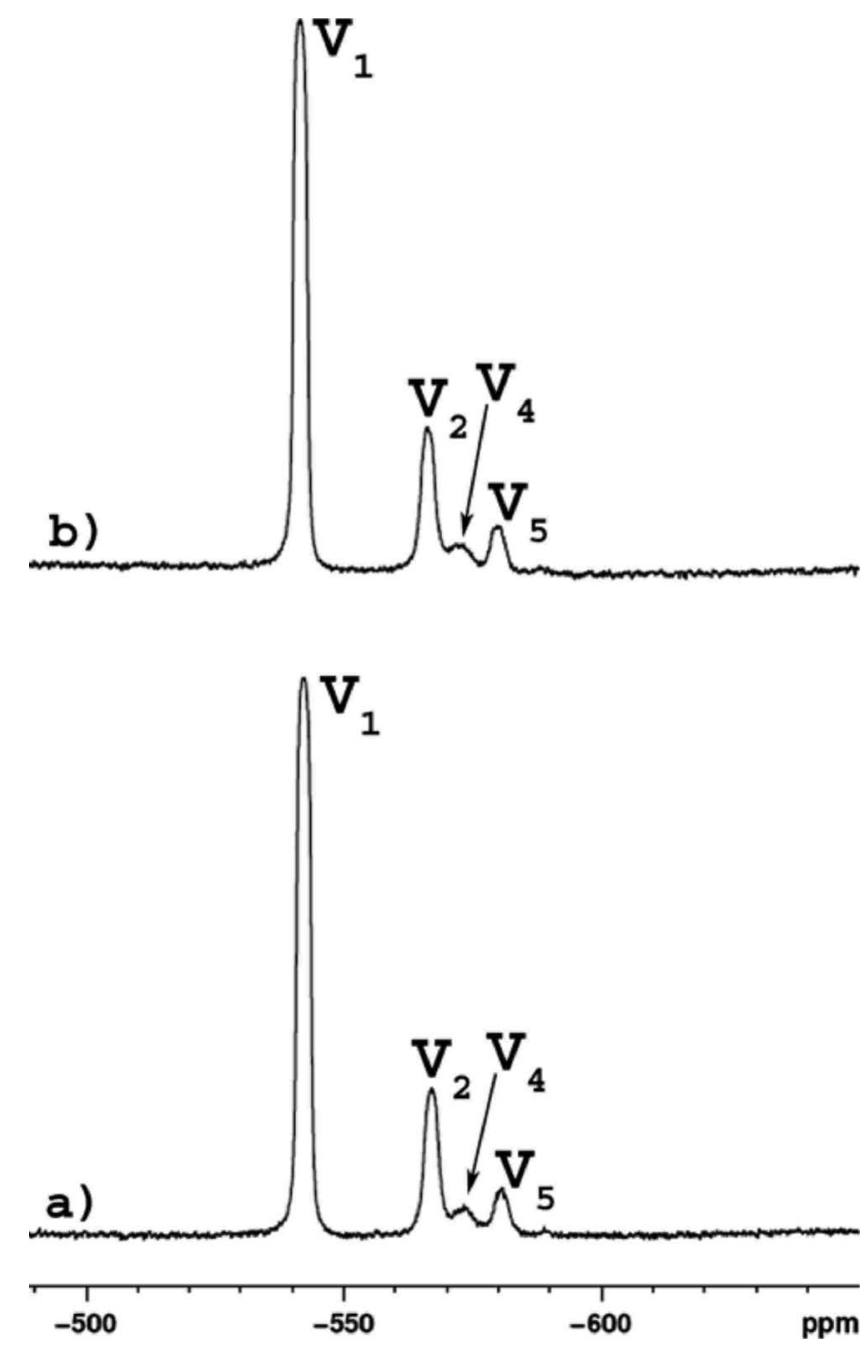

Figure 3. NMR spectra showing the presence of tetrahedrally coordinated vanadates $\left(\mathrm{V}_{1}, \mathrm{~V}_{2}, \mathrm{~V}_{4}\right.$, and $\left.\mathrm{V}_{5}\right)$ in $\mathrm{pH} 9.170 .5 \mathrm{M} \mathrm{NaCl}+10 \mathrm{mM} \mathrm{NaVO}$ solution used for microcapillary electrochemical experiments (a) immediately prior to experimentation and (b) 10 days later after completion of experiments.

also appears to slightly increase the corrosion current density. A small decrease in cathodic kinetics, as seen by a decrease in current density at $-1.3 \mathrm{~V}_{\mathrm{SCE}}$ in vanadate solutions, is largely offset by an increase in anodic kinetics, as seen by an increase in $i_{\text {pass }}$ observed in $\mathrm{NaVO}_{3}$ solutions. $\mathrm{NaVO}_{3}$ increases the breakdown potential of pure $\mathrm{Al}$ and does not appear to have an effect on the repassivation potential on the reverse scan.

Pure $\mathrm{Cu} .-\mathrm{NaVO}_{3}$ was observed to have little effect on the corrosion potential, corrosion current density, or repassivation potential on the reverse scan of pure $\mathrm{Cu}$. Pure $\mathrm{Cu}$ did not demonstrate passive behavior with an observable characteristic breakdown. However, $\mathrm{NaVO}_{3}$ was observed to have an effect on dissolution kinetics. Comparison of current density at $-1.3 \mathrm{~V}_{\mathrm{SCE}}$ shows that $\mathrm{NaVO}_{3}$ solutions slowed cathodic kinetics.

$\mathrm{Al} 4 \% \mathrm{Cu}$. $-\mathrm{Al} 4 \% \mathrm{Cu}$ was used as an analog material for the matrix of $\mathrm{Al}$ 2024-T3. $\mathrm{NaVO}_{3}$ was observed to shift the corrosion potential to more active potentials, and the corrosion current density was observed to decrease as a result of a decrease in cathodic kinetics. A relatively small increase in $E_{\text {pit }}$ was observed in $\mathrm{NaVO}_{3}$ solutions compared to increases observed on other intermetallic compounds. Vanadate increased the current density observed in the passive region of the anodic polarization scans. 


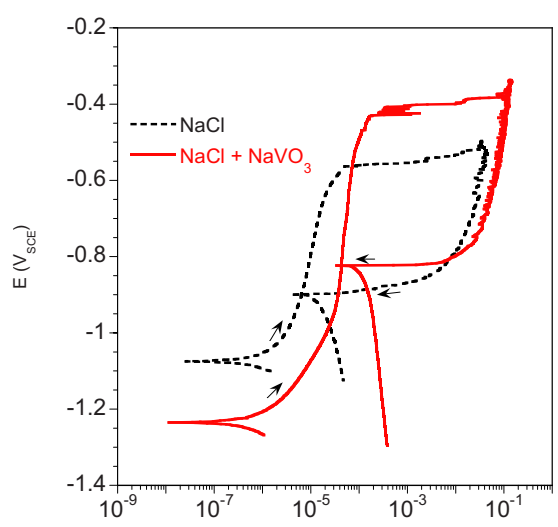

(a)

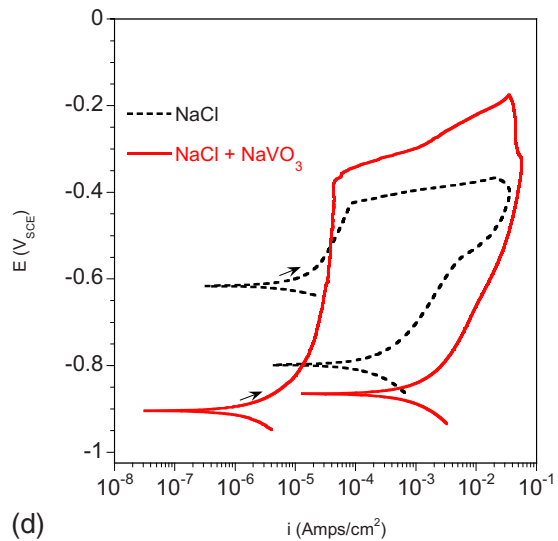

(d)

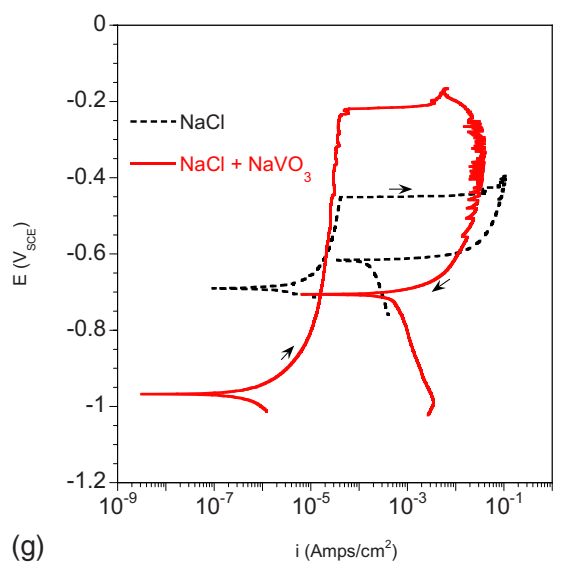

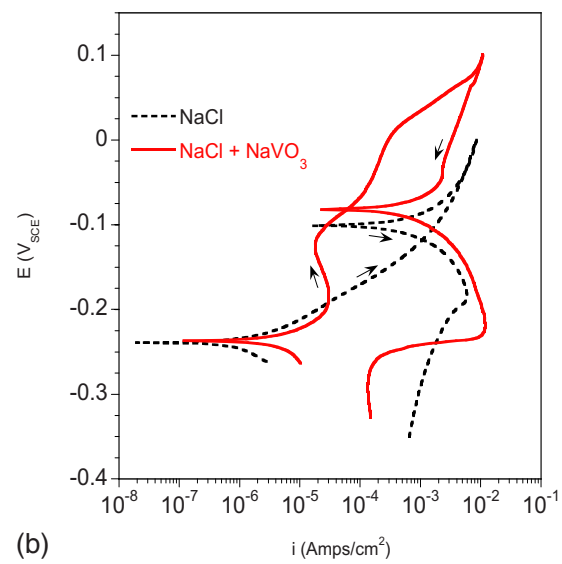
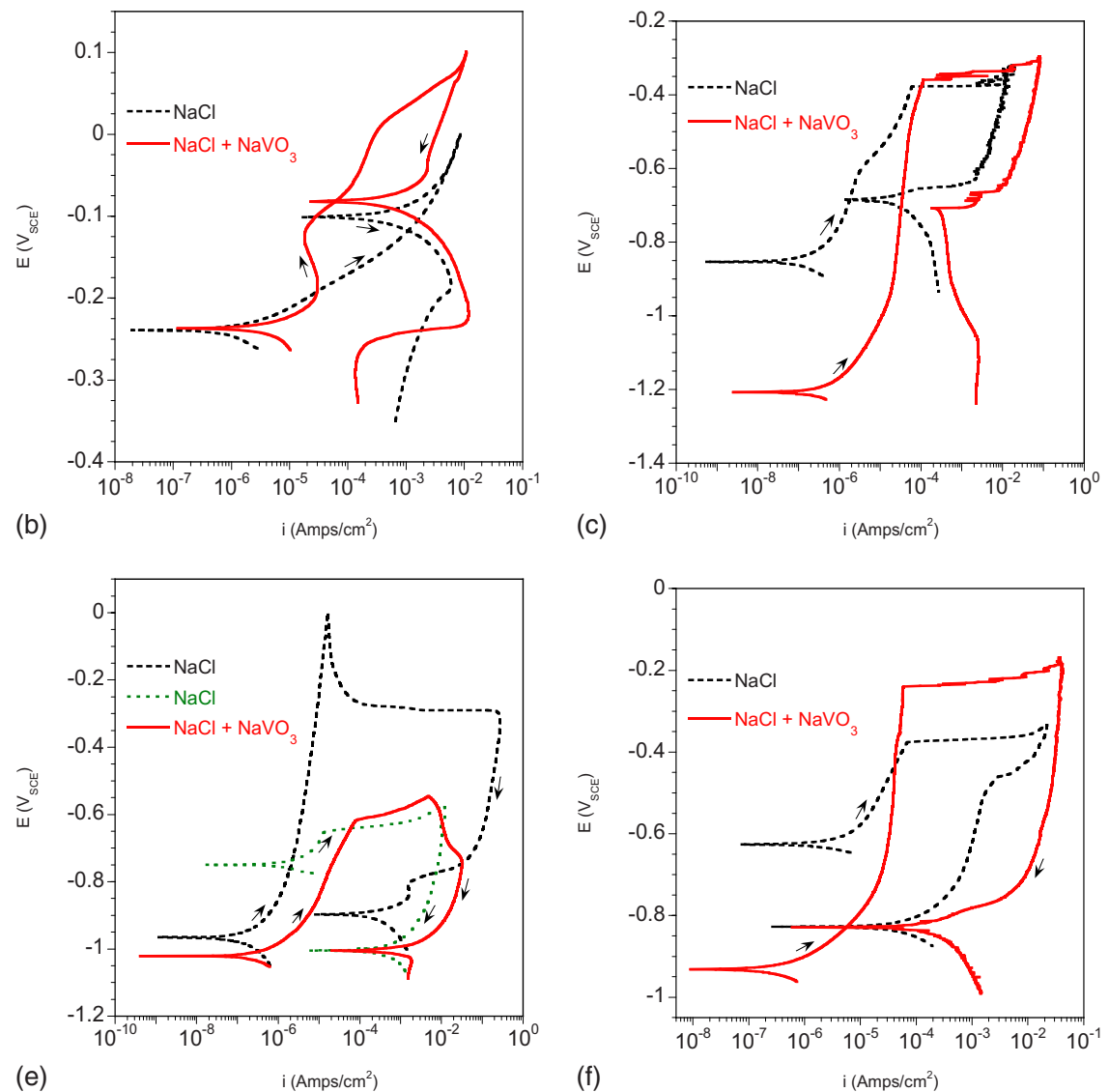

Figure 4. (Color online) Sample anodic polarization curves obtained using the microcapillary electrode in $\mathrm{pH} 9.170 .5 \mathrm{M} \mathrm{NaCl}$ solution with and without $10 \mathrm{mM} \mathrm{NaVO}$ for (a) pure $\mathrm{Al}$, (b) pure $\mathrm{Cu}$, (c) $\mathrm{Al} 4 \% \mathrm{Cu}$, (d) $\mathrm{Al}_{2} \mathrm{Cu}$, (e) $\mathrm{Al}_{2} \mathrm{CuMg}$, (f) $\mathrm{Al}_{7} \mathrm{Cu}_{2} \mathrm{Fe}$, and (g) $\mathrm{Al}_{20} \mathrm{Cu}_{2} \mathrm{Mn}_{3}$.

$\mathrm{Al}_{2} \mathrm{Cu}, \mathrm{Al}_{7} \mathrm{Cu}_{2} \mathrm{Fe}$, and $\mathrm{Al}_{20} \mathrm{Cu}_{2} \mathrm{Mn}$. - These three intermetallics were observed to behave similarly in $\mathrm{NaVO}_{3}$ solution. All three intermetallics showed a large shift in corrosion potential to more active potentials in $\mathrm{NaVO}_{3}$ solutions. $\mathrm{Al}_{7} \mathrm{Cu}_{2} \mathrm{Fe}$ and $\mathrm{Al}_{2} \mathrm{Cu}$ showed a decrease in corrosion current density in $\mathrm{NaVO}_{3}$ solution, while vanadate had little effect on the corrosion current density of $\mathrm{Al}_{20} \mathrm{Cu}_{2} \mathrm{Mn}_{3}$. These intermetallics showed an order of magnitude or more decrease in current density at $-1.3 \mathrm{~V}_{\mathrm{SCE}}$, indicating an overall decrease in cathodic kinetics. Further, the breakdown potential of all three intermetallics was observed to increase in $\mathrm{NaVO}_{3}$; however, $\mathrm{NaVO}_{3}$ had little effect on the current magnitude observed in the passive region of the anodic polarization curves.

$\mathrm{Al}_{2} \mathrm{CuMg}$. - A large degree of variability was observed in the anodic polarization curves of $\mathrm{Al}_{2} \mathrm{CuMg}$. This variability was most pronounced in the breakdown potential distribution. Breakdown in $\mathrm{Al}_{2} \mathrm{CuMg}$ is believed to be associated with loss in protection conferred by a $\mathrm{Cu}$-enriched layer that forms on the intermetallic surface as the intermetallic dissolves $\mathrm{Mg}$ and, to a lesser extent, Al. Two different reproducible behaviors were observed on $\mathrm{Al}_{2} \mathrm{CuMg}$ in $0.5 \mathrm{M} \mathrm{NaCl}$ solutions, which are shown in Fig. 4e. Most anodic polarization curves in $\mathrm{NaCl}$-only solutions showed passive behavior up to and above $-0.4 \mathrm{~V}_{\mathrm{SCE}}$. In some cases, the rapid scan rate resulted in polarization of sample intermetallics well beyond potentials necessary for breakdown, as illustrated by one of the $\mathrm{NaCl}$-only curves in Fig. 4e. In these cases, the potential of the plateau after breakdown was used for $E_{\text {pit }}$ values shown in cumulative probability plots. A small number of polarization curves in $\mathrm{NaCl}$-only solution were observed to have more noble corrosion potentials and more 


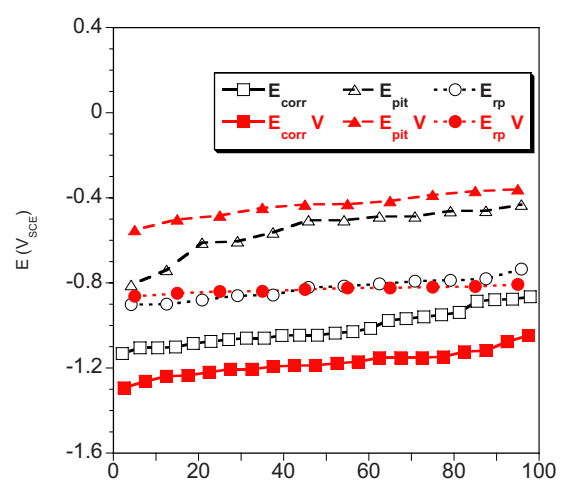

(a)

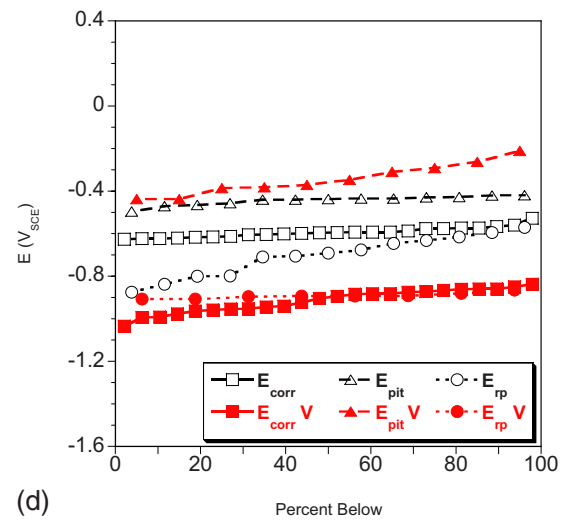

(d)

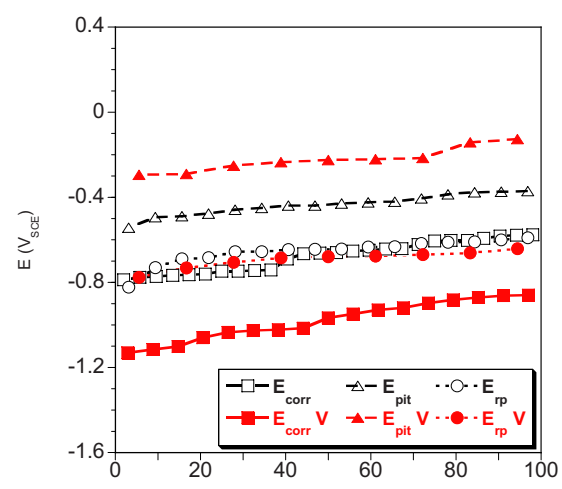

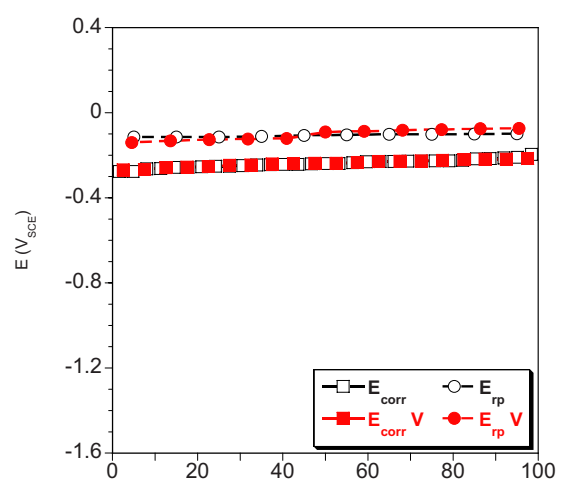

(b)

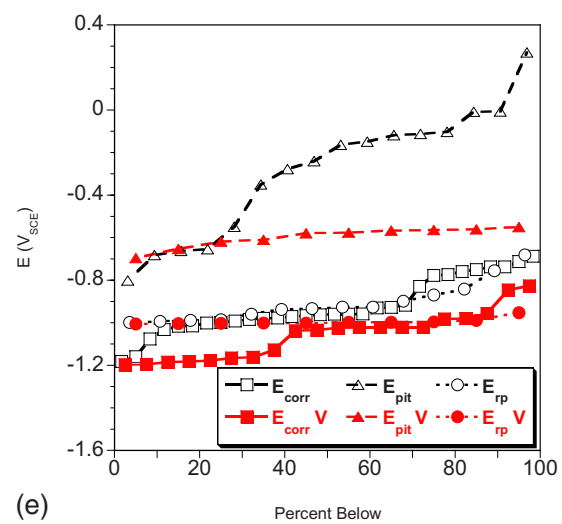

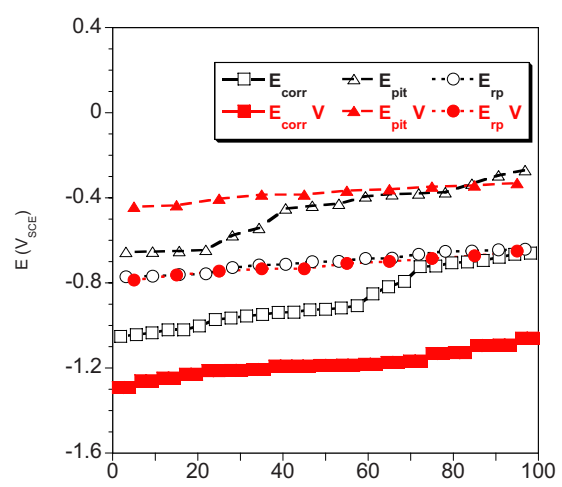

(c)

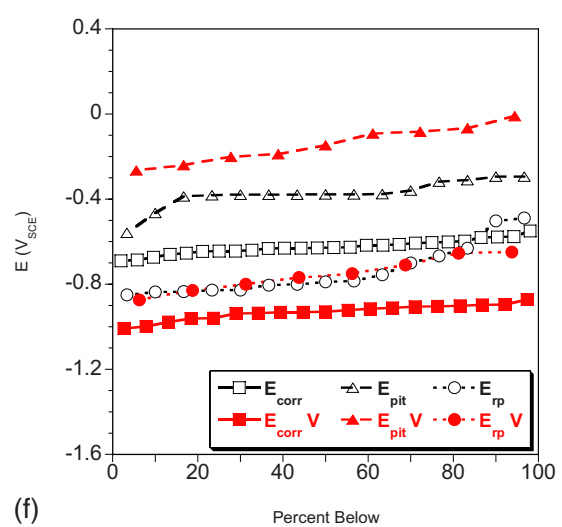

(g)

Percent Below

Figure 5. (Color online) Cumulative probability plots displaying $E_{\text {corr }}, E_{\mathrm{pit}}$, and $E_{\mathrm{rp}}$ of tested materials in pH $9.170 .5 \mathrm{M} \mathrm{NaCl}$ solution with and without $10 \mathrm{mM}$ $\mathrm{NaVO}_{3}$ for (a) pure $\mathrm{Al}$, (b) pure $\mathrm{Cu}$, (c) $\mathrm{Al} 4 \% \mathrm{Cu}$, (d) $\mathrm{Al}_{2} \mathrm{Cu}$, (e) $\mathrm{Al}_{2} \mathrm{CuMg}$, (f) $\mathrm{Al}_{7} \mathrm{Cu}_{2} \mathrm{Fe}$, and (g) $\mathrm{Al}_{20} \mathrm{Cu}_{2} \mathrm{Mn}_{3}$. $\mathrm{The}$ "V" in the legend indicates curves collected in solutions containing $\mathrm{NaVO}_{3}$.

active breakdowns in relation to the previously discussed $\mathrm{Al}_{2} \mathrm{CuMg}$ anodic polarization curves. Generally, the addition of $\mathrm{NaVO}_{3}$ resulted in much more reproducible behavior with less data scatter. For example, $\mathrm{Al}_{2} \mathrm{CuMg}$ in $\mathrm{NaCl}$ solutions had breakdown potentials scattered from approximately -0.8 to $0.2 \mathrm{~V}_{\mathrm{SCE}} \cdot \mathrm{NaVO}_{3}$ caused the data distribution to become much tighter, ranging from approximately -0.7 to $-0.6 \mathrm{~V}_{\mathrm{SCE}}$, which on average is a shift in breakdown potential to more active potentials. Interestingly, the breakdown potential distribution is shifted to lower potentials when vanadate is present in the solution. This behavior is different than that observed for other intermetallic compounds, where breakdown potentials are ennobled by vanadate additions. Additionally, on average, $\mathrm{NaVO}_{3}$ caused a small decrease in the corrosion potential and corrosion current density; however, larger passive current densities were observed in $\mathrm{NaVO}_{3}$ solutions. $\mathrm{NaVO}_{3}$ was observed to decrease the current density at $-1.3 \mathrm{~V}_{\mathrm{SCE}}$, an indication of suppressed cathodic kinetics.
In summary, all tested materials showed passive behavior and a breakdown, with the exception of pure $\mathrm{Cu}$. $\mathrm{NaVO}_{3}$ in approximately $\mathrm{pH} 9$ test solutions shifted the corrosion potential to more active potentials, increased the pitting potential, except for $\mathrm{Al}_{2} \mathrm{CuMg}$, and decreased the cathodic kinetics. A summary of averaged characteristic potentials and current densities from polarization experiments is found in Table I.

OCP and scanning electron microscopy images of Al 2024-T3 exposed to tetrahedral vanadate solutions. - Figure 8 is a plot of the OCP of Al 2024-T3 in aerated and deaerated $0.5 \mathrm{M} \mathrm{NaCl}$ solutions with and without $10 \mathrm{mM} \mathrm{NaVO}_{3}$. The solutions were not intentionally buffered in any way, and as a result the solution $\mathrm{pH}$ at initial sample exposure and during OCP measurement varied. Typically, the $\mathrm{pH}$ of actively aerated solutions would become more acidic during the measurement. For example, the $\mathrm{pH}$ was observed to drop from 9.17 to 6.72 and from 9.19 to 8.85 from the beginning 


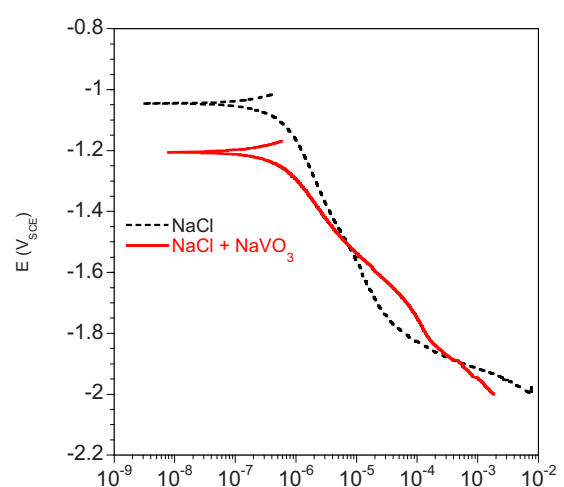

(a)

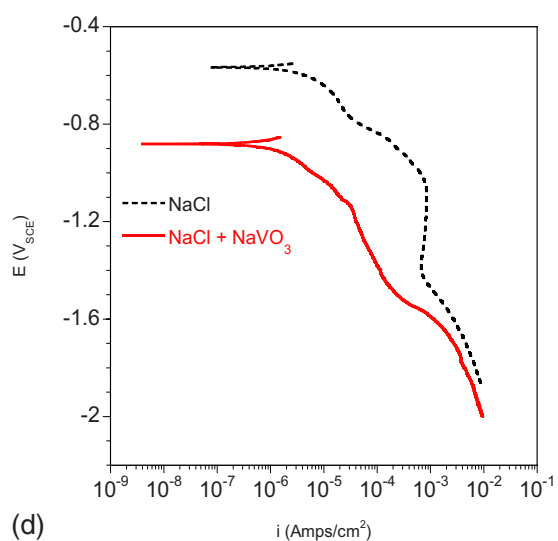

(d)

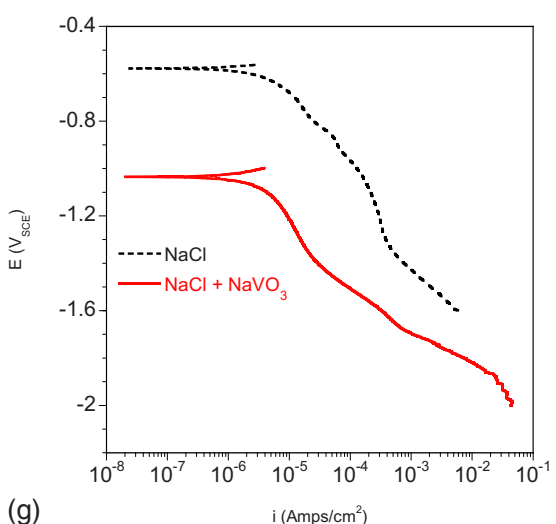

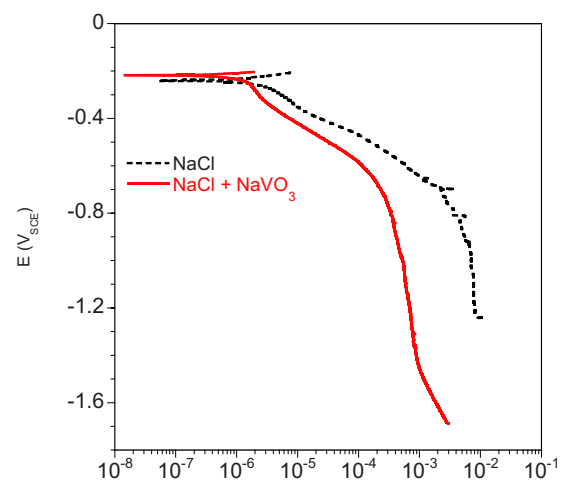

(b)

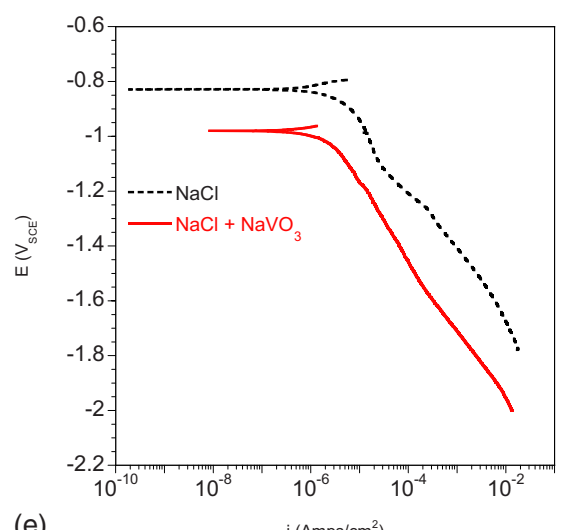

(e)

$i\left(A \mathrm{mps} / \mathrm{cm}^{2}\right)$

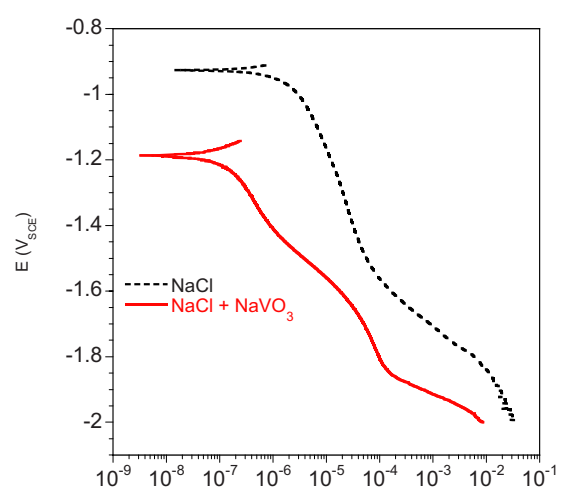

(c)

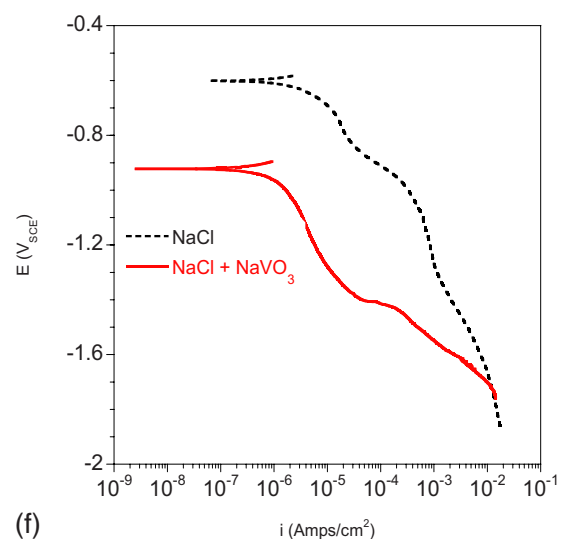

Figure 6. (Color online) Sample cathodic polarization curves obtained using the microcapillary electrode in $\mathrm{pH} 9.170 .5 \mathrm{M} \mathrm{NaCl}$ solution with and without $10 \mathrm{mM} \mathrm{NaVO}$ for (a) pure $\mathrm{Al}$, (b) pure $\mathrm{Cu}$, (c) $\mathrm{Al} 4 \% \mathrm{Cu}$, (d) $\mathrm{Al}_{2} \mathrm{Cu}$, (e) $\mathrm{Al}_{2} \mathrm{CuMg}$, (f) $\mathrm{Al}_{7} \mathrm{Cu}_{2} \mathrm{Fe}$, and $(\mathrm{g}) \mathrm{Al}_{20} \mathrm{Cu}_{2} \mathrm{Mn}_{3}$.

of OCP measurement until completion $4 \mathrm{~h}$ later for aerated solutions without $\mathrm{NaVO}_{3}$ and with $\mathrm{NaVO}_{3}$, respectively. In contrast, deaerated solutions would become more alkaline during the hour of deaeration prior to experimentation, and then $\mathrm{pH}$ would change little during the $4 \mathrm{~h}$ of OCP measurement. Similar to aerated solutions without $\mathrm{NaVO}_{3}$, deaerated solutions without $\mathrm{NaVO}_{3}$ typically were observed to have larger changes in $\mathrm{pH}$ compared to solutions with $\mathrm{NaVO}_{3}$. Vanadates can act as buffers, and this may be important with regard to the mechanism of vanadate solution inhibition. In aerated solutions without $\mathrm{NaVO}_{3}$, the OCP was observed to initially trend toward more noble potentials while cyclically fluctuating between approximately -0.89 and $-0.64 \mathrm{~V}_{\mathrm{SCE}}$ for the first 20-25 min of measurement before stabilizing to approximately $-0.62 \mathrm{~V}_{\mathrm{SCE}}$. Although $\mathrm{pH}$ was not measured during the experiment, it is suspected the $\mathrm{pH}$ was becoming more acidic with time as dissolved $\mathrm{CO}_{2}$ dissociated to and equilibrated with $\mathrm{CO}_{3}^{2-}$ and $\mathrm{HCO}_{3}^{-}$. In aerated solutions, the addition of $\mathrm{NaVO}_{3}$ maintained the OCP at values below
$-0.8 \mathrm{~V}_{\mathrm{SCE}}$ after $4 \mathrm{~h}$, and the $\mathrm{pH}$ remained alkaline. In contrast, in deaerated solutions the addition of $\mathrm{NaVO}_{3}$ was observed to increase the OCP from approximately -1.100 to $-0.85 \mathrm{~V}_{\mathrm{SCE}}$ after $4 \mathrm{~h}$.

Figures 9a-d show scanning electron microscopy (SEM) images of $\mathrm{Al} 2024-\mathrm{T} 3$ in aerated and deaerated $0.5 \mathrm{M} \mathrm{NaCl}$ solutions with and without $10 \mathrm{mM} \mathrm{NaVO}_{3}$ corresponding to the samples used in Fig. 8 after $4 \mathrm{~h}$ of OCP measurement. A comparison of samples in aerated solutions with and without vanadate show that in aerated solutions the presence of vanadate greatly decreased attack on and around intermetallic particles, Fig. 9a and b. The comparison is not completely direct, as the $\mathrm{pH}$ of the $\mathrm{NaVO}_{3}$-free solution drifted over experimentation to below $\mathrm{pH}$ 7. Regardless, the effect of vanadate even if only acting as a buffer is apparent. In particular, in aerated solutions without vanadate, nearly every intermetallic demonstrates attack, and a large number of intermetallics appear to have undergone complete dissolution or undercutting. In addition, a number of small, bright particles, possibly redistributed $\mathrm{Cu}$, are observed on the 


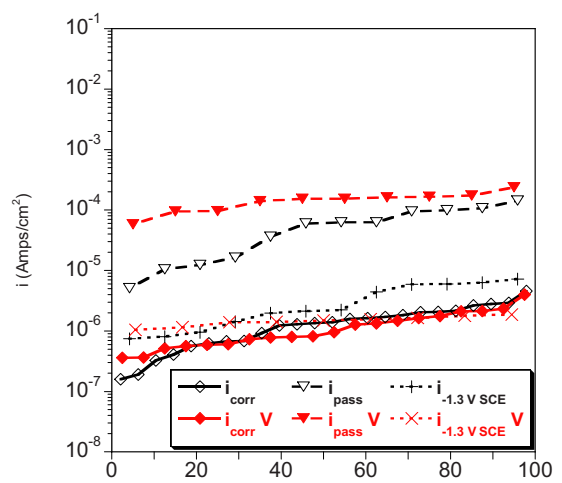

(a)

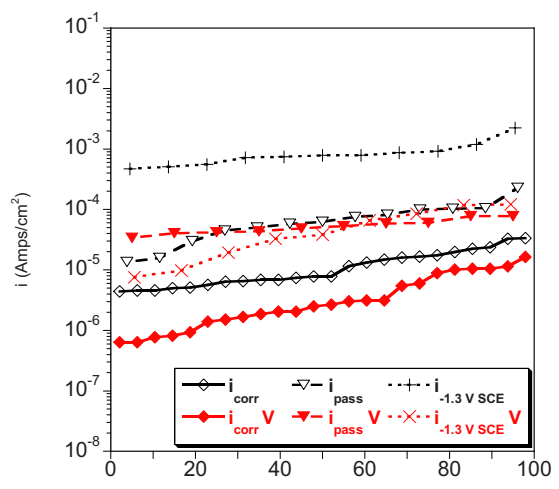

(d)

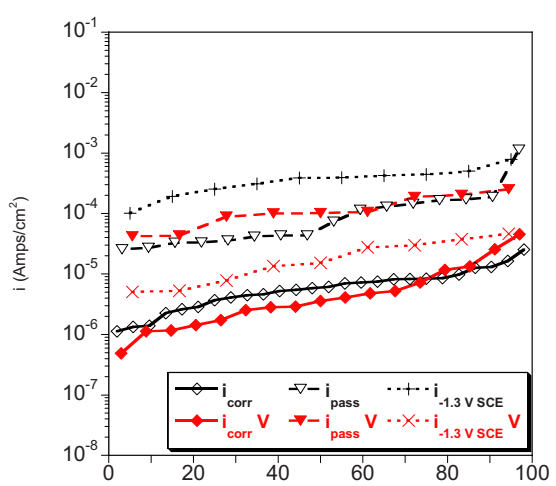

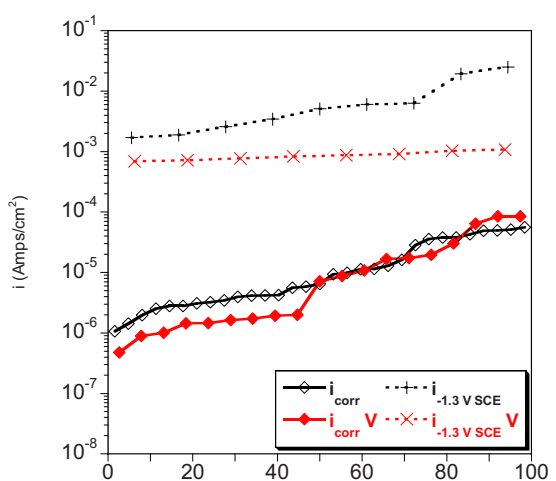

(b)

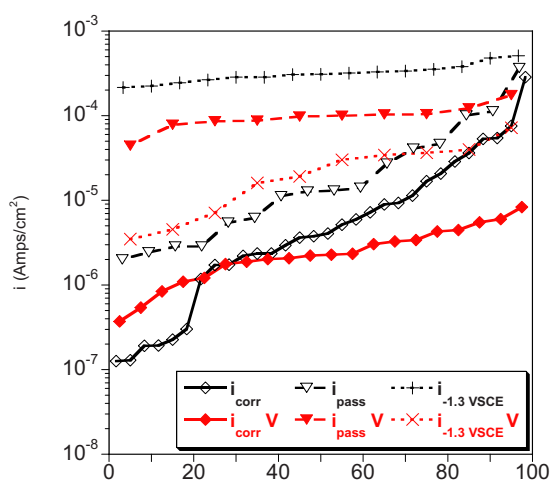

(e)

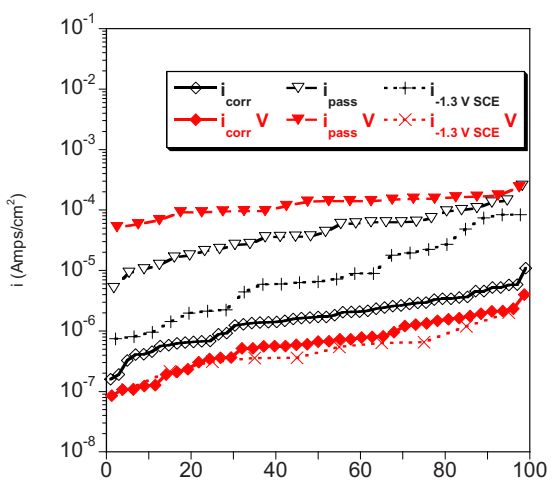

(c)

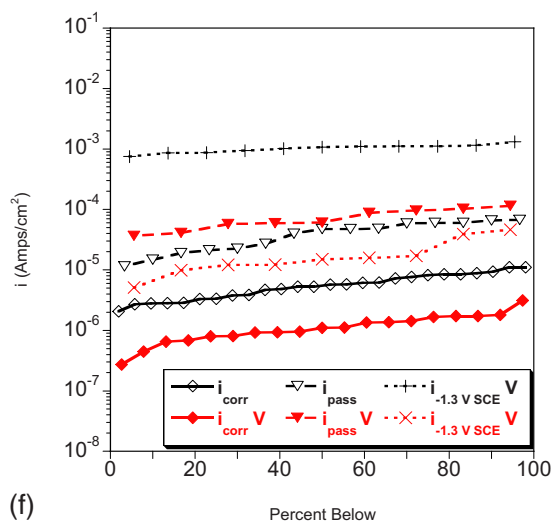

(g)

Percent Below

Figure 7. (Color online) Cumulative probability plots of $i_{\text {corr }}, i_{\text {pass }}$, and $i$ at $-1.3 \mathrm{~V}_{\mathrm{SCE}}$ of tested materials in $\mathrm{pH} 9.170 .5 \mathrm{M} \mathrm{NaCl}$ solution with and without $10 \mathrm{mM} \mathrm{NaVO}_{3}$ for (a) pure $\mathrm{Al}$, (b) pure $\mathrm{Cu}$, (c) $\mathrm{Al} 4 \% \mathrm{Cu}$, (d) $\mathrm{Al}_{2} \mathrm{Cu}$, (e) $\mathrm{Al}_{2} \mathrm{CuMg}$, (f) $\mathrm{Al}_{7} \mathrm{Cu}_{2} \mathrm{Fe}$, and (g) $\mathrm{Al}_{20} \mathrm{Cu}_{2} \mathrm{Mn}_{3}$. The "V" in the legend indicates curves collected in solutions containing $\mathrm{NaVO}_{3}$.

Table I. Averaged electrochemical data for intermetallics tested in approximately pH $9.170 .5 \mathrm{M} \mathrm{NaCl}$ solutions with and without $10 \mathrm{mM}$ $\mathrm{NaVO}_{3}$. A " $\mathrm{NaCl}$ " heading indicates data from $\mathrm{NaCl}$-only solutions, while a " $\mathrm{NaCl}+\mathrm{V}$ " heading indicates data collected in $\mathrm{NaCl}$ solution that contained $10 \mathrm{mM} \mathrm{NaVO}$.

\begin{tabular}{|c|c|c|c|c|c|c|c|c|c|c|c|c|}
\hline \multirow[b]{2}{*}{ Material } & \multicolumn{2}{|c|}{$E_{\text {corr }}\left(\mathrm{V}_{\mathrm{SCE}}\right)$} & \multicolumn{2}{|c|}{$E_{\mathrm{pit}}\left(V_{\mathrm{SCE}}\right)$} & \multicolumn{2}{|c|}{$E_{\mathrm{rp}}\left(V_{\mathrm{SCE}}\right)$} & \multicolumn{2}{|c|}{$i_{\text {corr }}\left(\mathrm{Amps} / \mathrm{cm}^{2}\right)$} & \multicolumn{2}{|c|}{$i_{\text {pass }}\left(\mathrm{Amps} / \mathrm{cm}^{2}\right)$} & \multicolumn{2}{|c|}{$i$ at $-1.3 V_{\mathrm{SCE}}\left(\mathrm{A} / \mathrm{cm}^{2}\right)$} \\
\hline & $\mathrm{NaCl}$ & $\mathrm{NaCl}+\mathrm{V}$ & $\mathrm{NaCl}$ & $\mathrm{NaCl}+\mathrm{V}$ & $\mathrm{NaCl}$ & $\mathrm{NaCl}+\mathrm{V}$ & $\mathrm{NaCl}$ & $\mathrm{NaCl}+\mathrm{V}$ & $\mathrm{NaCl}$ & $\mathrm{NaCl}+\mathrm{V}$ & $\mathrm{NaCl}$ & $\mathrm{NaCl}+\mathrm{V}$ \\
\hline & & & - & - & & & & $1.9 \times 10^{-5}$ & - & - & $7.9 \times 10^{-3}$ & $8.6 \times 10^{-4}$ \\
\hline & & & & & & & & & $5.9 \times 10^{-5}$ & $1.4 \times 10^{-4}$ & & \\
\hline & & & & & & & & & -5 & & & \\
\hline & & & & & & & $5.8 \times 1$ & $1.2 \times 10^{-6}$ & $4.1 \times 10^{-5}$ & $7.3 \times 10^{-5}$ & $1.0 \times 10^{-3}$ & $1.9 \times 10^{-5}$ \\
\hline $\mathrm{Al}_{2} \mathrm{Cu}$ & & & 0.44 & -0 & 0.70 & -0 . & $1.3 \times 10^{-5}$ & $4.5 \times 10^{-6}$ & $7.4 \times 10^{-5}$ & $5.4 \times 10^{-5}$ & $8.9 \times 10^{-4}$ & $5.5 \times 10^{-5}$ \\
\hline $\mathrm{Au}_{20} \mathrm{Cu}_{2} \mathrm{Mn}_{3}$ & 0.68 & -0.98 & -0.44 & -0.22 & -0.65 & -0.69 & $1.7 \times 10^{-6}$ & $7.9 \times 10^{-6}$ & $1.5 \times 10^{-4}$ & $1.3 \times 10^{-4}$ & $3.8 \times 10^{-4}$ & $2.1 \times 10^{-5}$ \\
\hline $\mathrm{Al}_{2} \mathrm{CuMg}$ & -0.92 & -1.06 & -0.29 & -0.60 & -0.91 & -0.99 & $2.2 \times 10^{-5}$ & $2.8 \times 10^{-6}$ & $4.8 \times 10^{-5}$ & $1.0 \times 10^{-4}$ & $3.2 \times 10^{-4}$ & $2.6 \times 10^{-5}$ \\
\hline
\end{tabular}




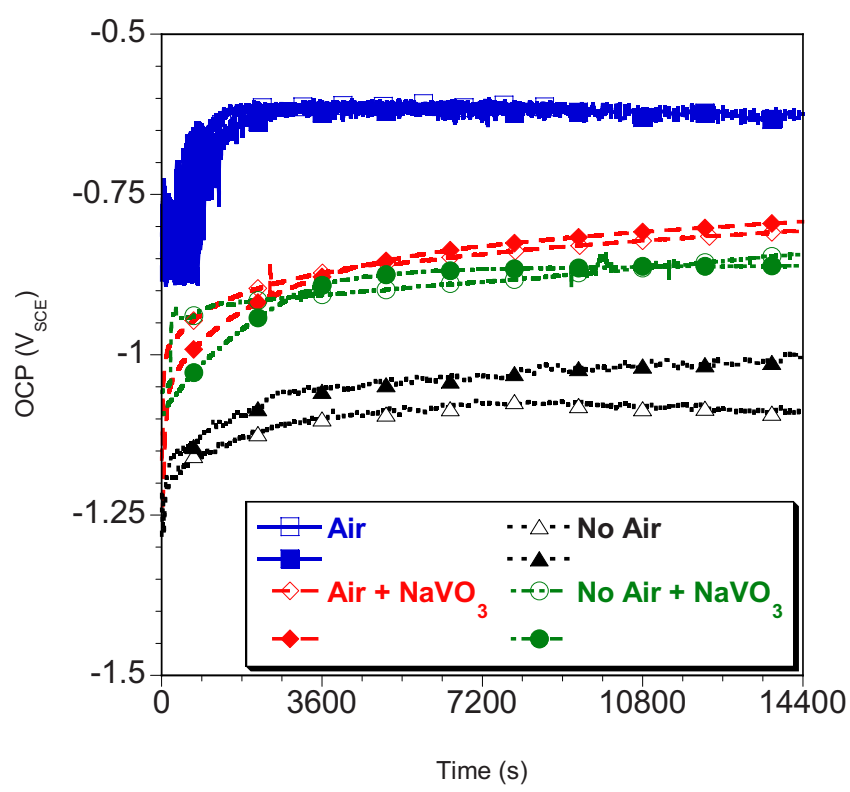

Figure 8. (Color online) OCP of Al 2024-T3 over $4 \mathrm{~h}$ in aerated and deaerated $\mathrm{pH} 9.170 .5 \mathrm{M} \mathrm{NaCl}$ with and without $10 \mathrm{mM} \mathrm{NaVO}_{3}$. Solutions were not intentionally buffered, and duplicate data are shown.

surface near pits. Previous studies have detailed the release and redistribution of metallic $\mathrm{Cu}$, observed around some pits, from $\mathrm{Al}_{2} \mathrm{CuMg}$ intermetallics. ${ }^{5,38}$ Although there is some attack at the periphery of intermetallic particles in aerated solutions with vanadate, for the most part intermetallics remain intact. As seen in Fig. $9 \mathrm{c}$ and $\mathrm{d}$, vanadates also appear to decrease the amount of attack around the periphery of intermetallic particles in deaerated solutions. Circumferential attack is seen around round intermetallics in deaerated solutions without vanadate to a larger degree than in deaerated solutions with vanadate. Although no direct chemical analysis was performed, these small, round intermetallics are likely $\mathrm{Al}_{2} \mathrm{CuMg}$ and $\mathrm{Al}_{2} \mathrm{Cu}^{4,5,39}$ In both aerated and deaerated solutions, $\mathrm{NaVO}_{3}$ appears to greatly decrease the amount of trenching attack observed around intermetallic particles.

Figure 10 shows duplicate anodic polarization curves of the $\mathrm{Al}$ 2024-T3 sheet in aerated $0.5 \mathrm{M} \mathrm{NaCl}$ with $10 \mathrm{mM} \mathrm{NaVO}_{3}$ at $\mathrm{pH}$ 9.17. The purpose of this experiment was to show a correlation between electrochemical features of the real alloy with observed behavior from the microcell. The curves show an inflection between -0.75 and $-0.8 \mathrm{~V}_{\mathrm{SCE}}$, which corresponds well to the breakdown of $\mathrm{Al}_{2} \mathrm{CuMg}$ observed in $\mathrm{NaVO}_{3}$ solution from microcell results and is likely the onset of $\mathrm{Mg}$ dissolution. Further, breakdown is observed at approximately $-0.575 \mathrm{~V}_{\mathrm{SCE}}$, which corresponds to the breakdown of pure $\mathrm{Al}$.

Suppressed $\mathrm{Al}_{2} \mathrm{CuMg}$ dissolution in tetrahedral vanadate solutions. - Figures $11 \mathrm{a}$ and $\mathrm{b}$ show plots of the resultant current responses after potentiostatic hold experiments on Al 2024-T3 sheets in $0.5 \mathrm{M} \mathrm{NaCl}$ at $\mathrm{pH} 9.17$ with and without $10 \mathrm{mM} \mathrm{NaVO}_{3}$. Figure $11 \mathrm{c}$ shows total charge passed from Fig. 11a and b. Polished Al 2024-T3 samples were activated for $1 \mathrm{~s}$ at $1 \mathrm{~V}_{\mathrm{SCE}}$ and then held at different potentials spanning a range of expected intermetallic breakdown for $120 \mathrm{~s}$ to observe intermetallic and surface repassivation once activated. For samples exposed to the $\mathrm{NaCl}$-only solutions, the sample held at $-0.9 \mathrm{~V}_{\mathrm{SCE}}$ repassivated after activation; however, potential holds at more noble potentials produce a distinct transient. This is consistent with the breakdown of $\mathrm{Al}_{2} \mathrm{CuMg}$ observed in Fig. $5 \mathrm{e}$ for $\mathrm{NaCl}$-only solutions, although pure $\mathrm{Al}$ is also expected to break down in this range of potentials. The transient is believed to be associated with the dissolution of $\mathrm{Mg}$ from $\mathrm{Al}_{2} \mathrm{CuMg}$ intermetallic particles, which have shown dealloying at similar potentials. ${ }^{4}$
The plot shows that, regardless of potential hold, $\mathrm{Al}_{2} \mathrm{CuMg}$ dissolution is nearly complete within $30 \mathrm{~s}$. Similar behavior was observed in samples exposed to vanadate solutions, where, once activated, samples held at potentials at or more positive than $-0.8 \mathrm{~V}_{\mathrm{SCE}}$ exhibited dissolution transients. However, for each curve obtained in $\mathrm{NaVO}_{3}$ solution, the current response had a lower magnitude than the current response at corresponding potentials obtained in $\mathrm{NaCl}-$ only solutions. A comparison of total charge passed in Fig. 11c shows that at all potentials except $-0.6 \mathrm{~V}_{\mathrm{SCE}}$, vanadate reduced the total charge passed.

\section{Discussion}

Cathodic inhibition from tetrahedrally coordinated vanadate species.-Figure 2 shows that an inverse relationship exists between $\mathrm{NaVO}_{3}$ concentration and inhibition of cathodic kinetics at $\mathrm{pH}$ 5.1, where dilute solutions perform better than moreconcentrated solutions. The $\mathrm{pH}$ and concentration of these experiments was chosen purposely to be near the transition from solutions dominated by octahedral species $\left(0.25 \mathrm{M} \mathrm{NaVO}_{3}\right)$ to those dominated by tetrahedral species $\left(0.0025 \mathrm{M} \mathrm{NaVO}_{3}\right)$. The dilute $\mathrm{NaVO}_{3}$ solution contains relatively more tetrahedral vanadate as compared to the concentrated $\mathrm{NaVO}_{3}$ solution, which contains relatively little tetrahedral species compared to octahedral species. At this $\mathrm{pH}$, concentrated $\mathrm{NaVO}_{3}$ solutions are expected to predominately have decavanadate species, which are octahedrally coordinated. As the concentration of $\mathrm{NaVO}_{3}$ in solution decreases, tetrahedral species become more prevalent. The increased presence of tetrahedral species correlates with the reduced cathodic kinetics observed in cathodic polarization experiments. This is in agreement with other work, which has suggested that tetrahedrally coordinated vanadates inhibit the corrosion of Al 2024-T3. ${ }^{18,20-22,27}$ However, the moreconcentrated $\mathrm{NaVO}_{3}$ solution containing predominately octahedral decavanadate appears to be a modest cathodic inhibitor at this $\mathrm{pH}$, in contrast to the findings of previous work, which suggest that decavanadates are reduced and possibly increase corrosion. ${ }^{18,20}$ If decavanadate is not responsible for the observed inhibition, then the small concentrations of tetrahedral species in solution are likely responsible.

Suppression of $\mathrm{Al}_{2} \mathrm{CuMg}$ breakdown.- In alkaline $\mathrm{NaCl}$ solutions, a portion of the total $\mathrm{Al}_{2} \mathrm{CuMg}$ intermetallic particle population would be expected to break down at potentials as low as $-0.8 \mathrm{~V}_{\mathrm{SCE}}$. At the OCP in aerated $\mathrm{NaCl}$ solutions, which fluctuates approximately from -0.9 and $-0.75 \mathrm{~V}_{\mathrm{SCE}}$ before the solution begins to become acidic from dissolved atmospheric $\mathrm{CO}_{2}$ with eventual OCP stabilization near $-0.65 \mathrm{~V}_{\mathrm{SCE}}, \mathrm{Al}_{2} \mathrm{CuMg}$ breakdown leads to selective $\mathrm{Mg}$ dissolution and formation of $\mathrm{Cu}$-enriched local cathodes. In contrast, $\mathrm{Al}_{2} \mathrm{CuMg}$ in alkaline-aerated $\mathrm{NaCl}$ with $10 \mathrm{mM}$ $\mathrm{NaVO}_{3}$ is expected to break down at potentials only above $-0.7 \mathrm{~V}_{\mathrm{SCE}}$. However, the OCP in $\mathrm{NaVO}_{3}$ solutions after $4 \mathrm{~h}$ was observed to remain below approximately $-0.79 \mathrm{~V}_{\mathrm{SCE}}$. The shift in alloy OCP to more active potentials is a result of a decrease in cathodic kinetics observed on the matrix and all intermetallic phases, as seen in Fig. 6. Iannuzzi et al. argue that decreased kinetics might be the result of the adsorption of monovanadate to the surface, blocking reactive sites on intermetallic particles and displacing $\mathrm{Cl}^{-}$ from the matrix surface. ${ }^{20}$ The consequence of decreased cathodic kinetics and the resultant shift in OCP, combined with a small increase in $\mathrm{Al}_{2} \mathrm{CuMg}$ breakdown potential observed in $\mathrm{NaVO}_{3}$ solutions, is that $\mathrm{Al}_{2} \mathrm{CuMg}$ intermetallics remain "inefficient" cathodes. If $\mathrm{Cu}$-enriched particles resulting from $\mathrm{Al}_{2} \mathrm{CuMg}$ dissolution are assumed to act like pure $\mathrm{Cu}$ (Fig. $6 \mathrm{~b}$ ), then the rate at which cathodic reactions are supported is greater than compared to rates supported by intact $\mathrm{Al}_{2} \mathrm{CuMg}$ in $\mathrm{NaVO}_{3}$ solutions (Fig. 6e).

Variation in anodic behavior of $\mathrm{Al}_{2} \mathrm{CuMg}$. - As seen in Fig. 4e, two different anodic polarization behaviors were observed in $\mathrm{NaCl}$ solutions. In a minority of cases, $E_{\text {corr }}$ was observed to be $-0.8 \mathrm{~V}_{\mathrm{SCE}}$ or more noble with breakdown at potentials near $-0.6 \mathrm{~V}_{\mathrm{SCE}}$ or more 


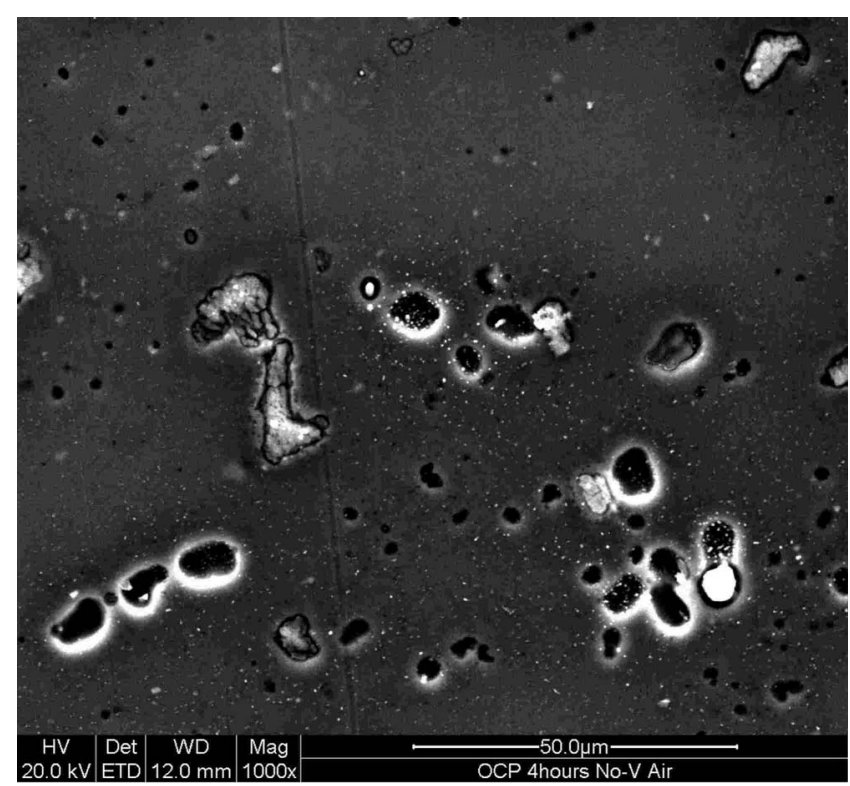

(a)

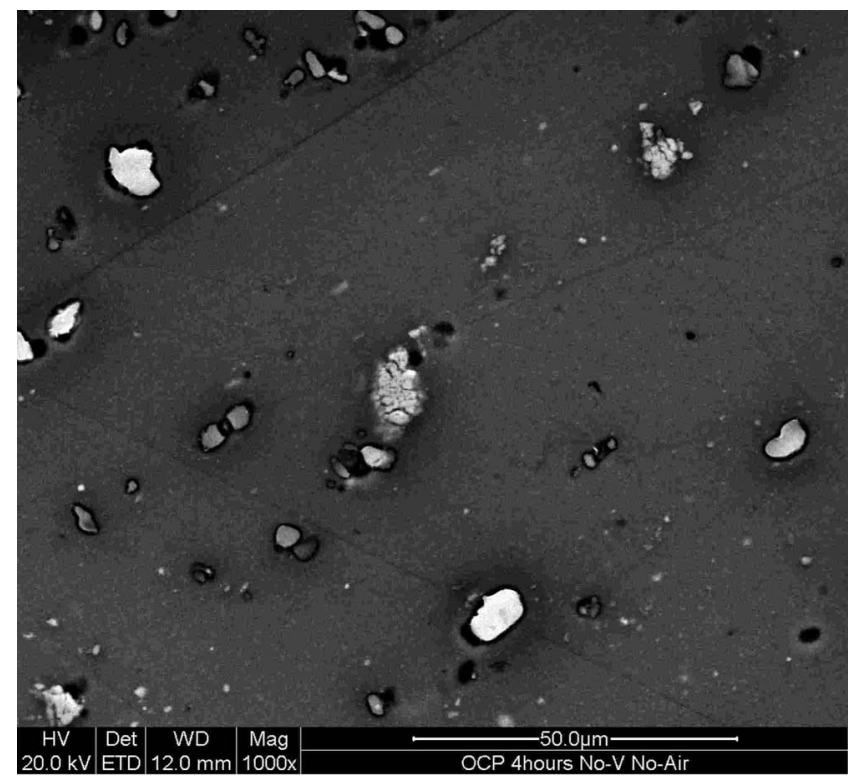

(c)

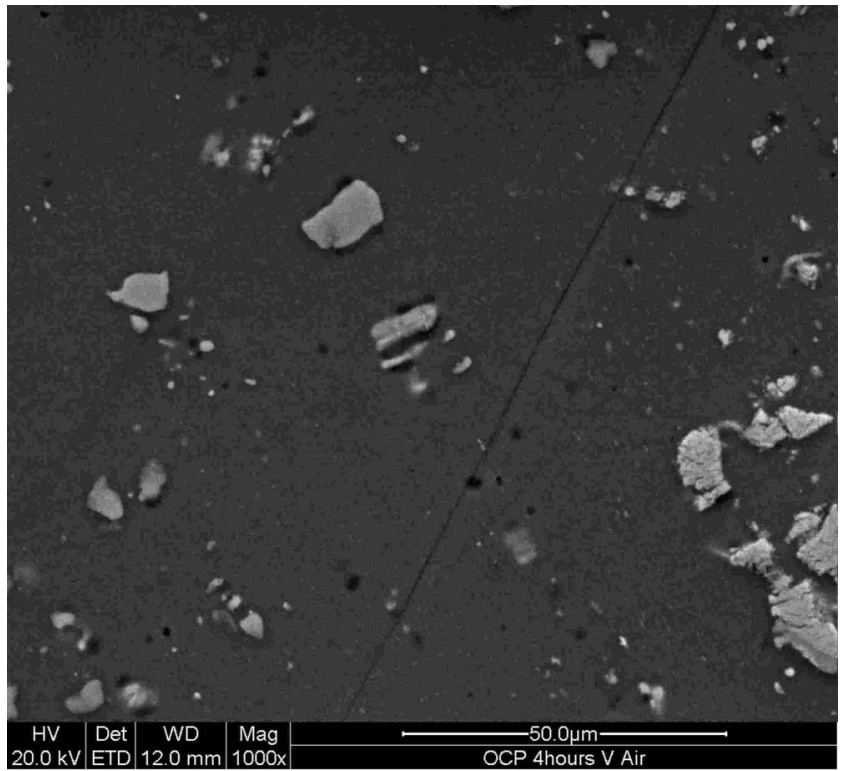

(b)

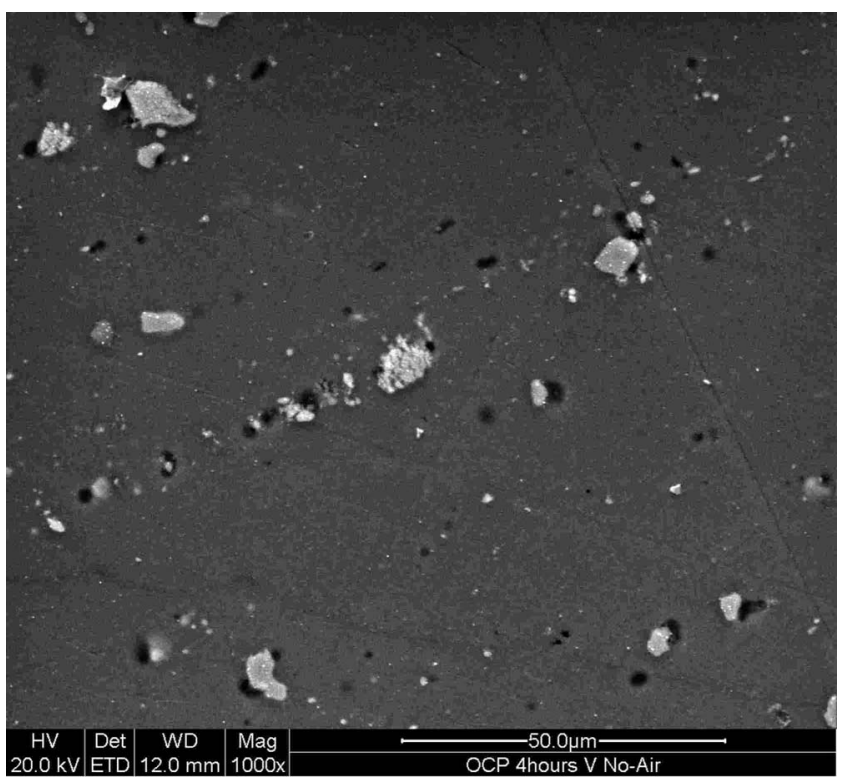

(d)

Figure 9. SEM images of $\mathrm{Al} 2024-\mathrm{T} 3$ after $4 \mathrm{~h}$ of OCP measurement in $0.5 \mathrm{M} \mathrm{NaCl}$ solutions with an initial approximate $\mathrm{pH} 9.17$ and (a) aeration, (b) aeration with $10 \mathrm{mM} \mathrm{NaVO}_{3}$, (c) deaeration, and (d) deaeration with $10 \mathrm{mM} \mathrm{NaVO}_{3}$.

active. Yoon and Buchheit reported that $\mathrm{Al}_{2} \mathrm{CuMg}$ has an initial OCP in $0.5 \mathrm{M} \mathrm{NaCl}$ near $-1.2 \mathrm{~V}_{\mathrm{SCE}}$, which drifts and becomes stable between -0.86 and $-0.76 \mathrm{~V}_{\mathrm{SCE}}$ after approximately $1000 \mathrm{s.}{ }^{12}$ It was claimed that $\mathrm{Al}_{2} \mathrm{CuMg}$ experienced transient dissolution followed by passivation and stable low-rate dissolution with an OCP near $-0.8 \mathrm{~V}_{\mathrm{SCE}}{ }^{12}$ It seems possible that anodic polarization of $\mathrm{Al}_{2} \mathrm{CuMg}$ that showed corrosion potentials at approximately $-0.8 \mathrm{~V}_{\mathrm{SCE}}$ had already experienced transient dissolution compared to experiments that showed more active corrosion potentials near the $-1.2 \mathrm{~V}_{\mathrm{SCE}} \mathrm{OCP}$ reported by Yoon. Generally, the wide variably in $E_{\text {corr }}$ and $E_{\text {pit }}$ data obtained on $\mathrm{Al}_{2} \mathrm{CuMg}$ in $\mathrm{NaCl}$ could be attributed to samples being at various stages of dissolution prior to polarization, perhaps a result of extreme sensitivity to variation in polishing conditions. In contrast, the behavior of $\mathrm{Al}_{2} \mathrm{CuMg}$ in $\mathrm{NaVO}_{3}$ solutions showed little variability in electrochemical response, which is possibly evidence that vanadates control the process of dealloying and redistribution of $\mathrm{Cu}$ on the surface, resulting in overall suppression of $\mathrm{Al}_{2} \mathrm{CuMg}$ dissolution. The breakdown potential distribution measured in vanadate solutions is shifted to more active potentials compared to vanadate-free solutions. This is consistent with the idea that vanadates suppress $\mathrm{Mg}$ dissolution from the phase. In this case, suppression of $\mathrm{Mg}$ dissolution would result in a thinner, lessprotective $\mathrm{Cu}$-enriched layer on the surface of the phase that breaks down at lower potentials. Even though breakdown of $\mathrm{Al}_{2} \mathrm{CuMg}$ is shifted to lower potentials when vanadate is present in solution, the corrosion potential of the alloy remains below the $\mathrm{Al}_{2} \mathrm{CuMg}$ breakdown potential distribution, and corrosion susceptibility is decreased.

Vanadate buffering and circumferential attack.- In this work and in previous work, it has been observed that vanadate solutions act as buffers, requiring more alkali or acid to adjust the $\mathrm{pH}$ than 


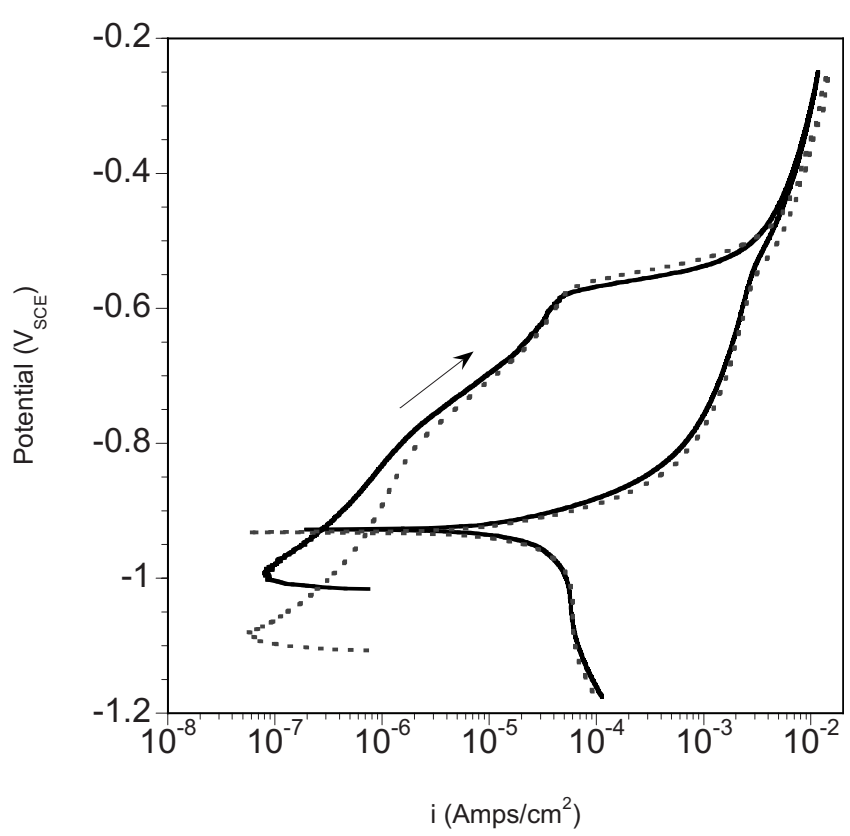

Figure 10. Duplicate anodic polarization curves of a bulk Al 2024-T3 sheet in aerated $0.5 \mathrm{M} \mathrm{NaCl}+10 \mathrm{mM} \mathrm{NaVO}_{3}$ solution at $\mathrm{pH} 9.17$.

necessary for equivalent vanadate-free solutions. ${ }^{18}$ Particularly, for this work, once vanadate solutions were adjusted to $\mathrm{pH}$ values near 9, the solution $\mathrm{pH}$ remained stable for months. In contrast, equivalent $\mathrm{NaCl}$ solutions adjusted to $\mathrm{pH}$ values near 9 would quickly become more acidic as carbonic acid formed from dissolved atmospheric $\mathrm{CO}_{2}$. Leclère et al. have argued that the presence of a buffer or weak acid can suppress alkaline dissolution near cathodic sites resulting from hydroxyl produced by oxygen reduction, which results in large cathodic currents that drive pitting and localized attack more than observed in unbuffered solutions. ${ }^{30,31}$ The production of reducible $\mathrm{H}^{+}$at sites of local attack may contribute to the increased cathodic currents. A rough estimate of buffering capacity, $\beta$, for both carbonate and vanadate at $\mathrm{pH} 9.17$ is easily calculated using the following simplified equation

$$
\beta=2.303 \frac{K_{\mathrm{a}} C_{\mathrm{t}}\left[H^{+}\right]}{\left(K_{\mathrm{a}}+\left[H^{+}\right]\right)^{2}}
$$

where $K_{\mathrm{a}}$ is the acid dissociation constant and $C_{\mathrm{t}}$ is the total concentration of acid and base or total buffer concentration. ${ }^{40}$ At $\mathrm{pH}$ 9.2, the dominant species from atmospheric $\mathrm{CO}_{2}$ in solution are $\mathrm{HCO}_{3}^{-}$and $\mathrm{CO}_{3}^{2-}$, which have a $\mathrm{p} K_{\mathrm{a}}$ of 10.33 and a total concentration of approximately $0.025 \mathrm{M}$, which gives a buffering capacity of $0.0035 \mathrm{M} / \mathrm{pH}$ unit. ${ }^{35,41}$ If $\mathrm{pH} 9.1710 \mathrm{mM} \mathrm{NaVO}_{3}$ is assumed to be dominated by monomeric vanadate, a $\mathrm{p} K_{\mathrm{a}}$ of 8.2 is appropriate (other tetrahedral vanadates have $\mathrm{p} K_{\mathrm{a}}$ values ranging from 7.92 to 9.1 ) and gives a buffering capacity of $0.002 \mathrm{M} / \mathrm{pH}$ unit. ${ }^{42,43}$ At this $\mathrm{pH}$, the contribution of vanadate as a buffer is small compared to carbonate, while both seem to be relatively ineffective buffers. Figure 9a shows an $\mathrm{Al} 2024-\mathrm{T} 3$ sample exposed to $0.5 \mathrm{M} \mathrm{NaCl}$ without vanadate, which is analogous to a nearly unbuffered solution. The observation of circumferential attack and white corrosion product around intermetallics is consistent with initial alkaline attack from increased $\mathrm{pH}$ near cathodic sites, supporting oxygen reduction followed by aggressive pitting and crevice corrosion around intermetallics. In vanadate-free unbuffered deaerated $\mathrm{NaCl}$ solutions (Fig. 9c), despite the lack of oxygen, attack and trenches around intermetallic particles are still observed. In contrast, the degree of attack in alkaline deaerated (Fig. 9d), and in particular aerated (Fig. 9b), $\mathrm{NaCl}$ solutions that contain $\mathrm{NaVO}_{3}$ is significantly less than observed on corresponding $\mathrm{NaVO}_{3}$-free samples. There is some attack near in-

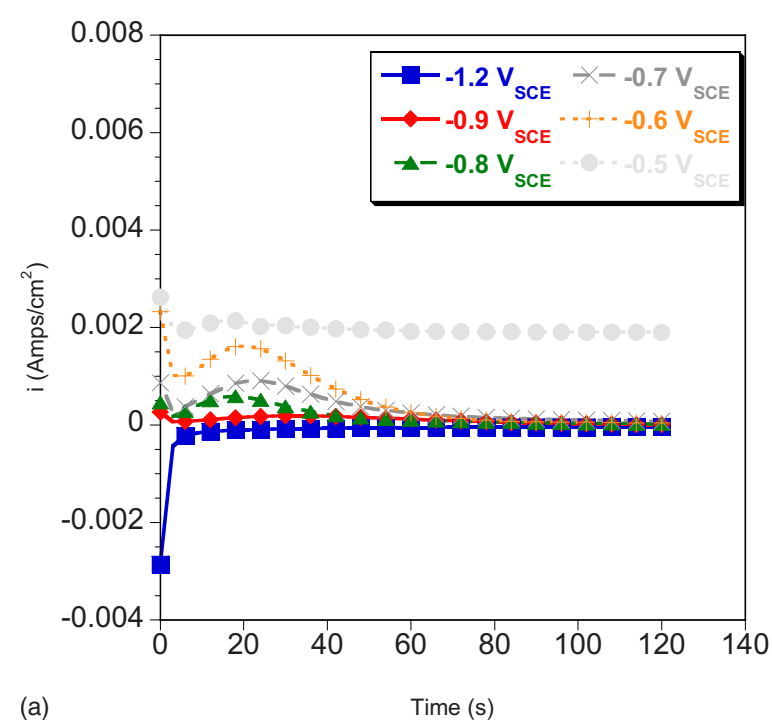

(a)
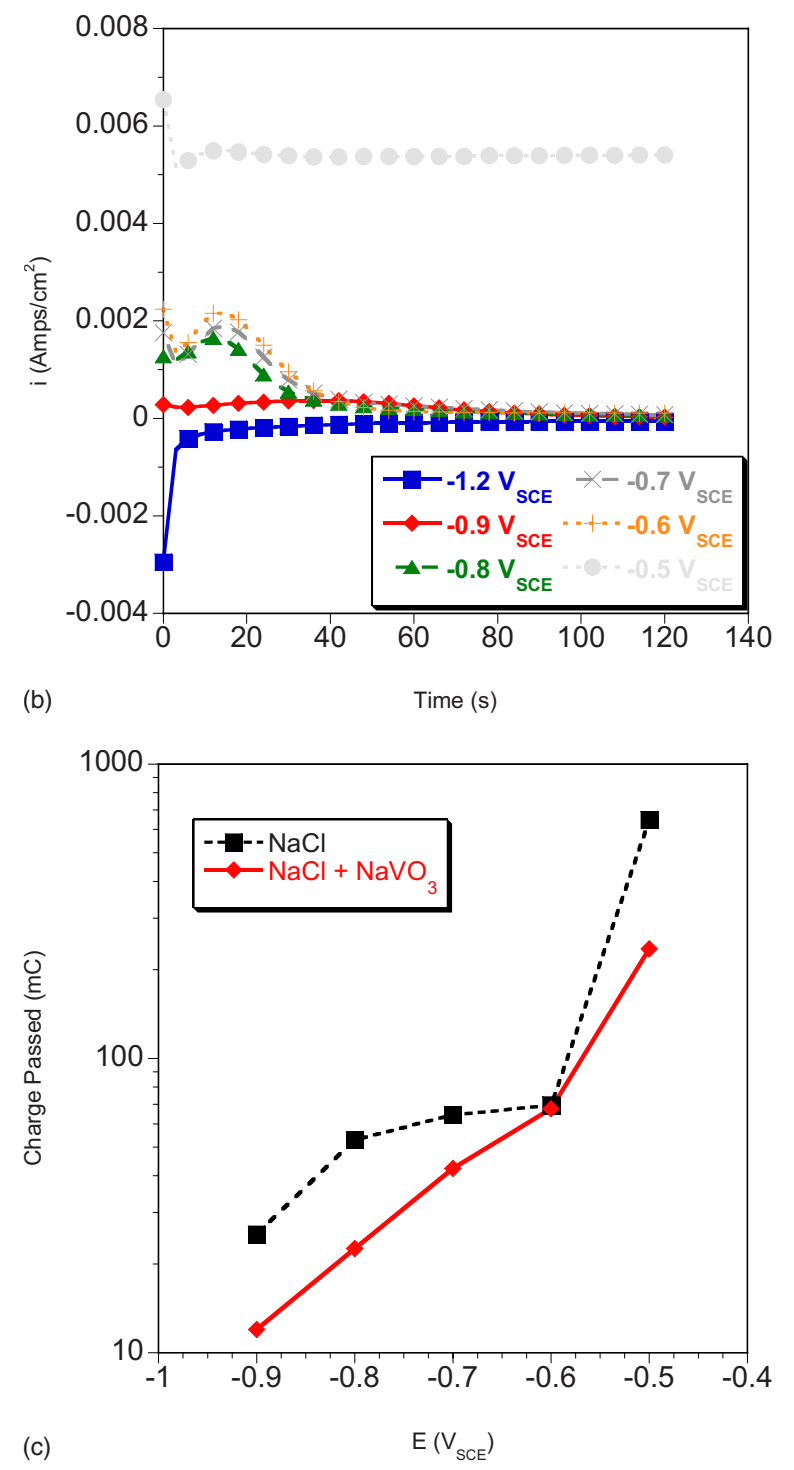

Figure 11. (Color online) Current response of potentiostatic hold experiments on $\mathrm{Al} 2024-\mathrm{T} 3$ in $\mathrm{pH} 9.170 .5 \mathrm{M} \mathrm{NaCl}$ (a) with $10 \mathrm{mM} \mathrm{NaVO}_{3}$ and (b) without $\mathrm{NaVO}_{3}$. (c) Summary of total charge passed as a function of potential hold for $a$ and $b$. 
termetallic particles, but complete circumferential attack of intermetallics is not observed. If vanadate were assumed to have an effect as a buffer, this would be consistent with previous observations of attack on $\mathrm{Al}-\mathrm{Cu}$ alloys in buffered and unbuffered solution, where more trenching is observed around intermetallics in unbuffered solutions as a result of alkalinization, while buffers decrease trenching by neutralizing local cathodic alkalinization. ${ }^{30,31}$ However, it has also been previously observed that total cathodic current is greater in buffered solutions because current is not used up for alkalinization and cathodic attack. ${ }^{30,31}$ This is in contrast to current microcell results, which show decreases in cathodic kinetics in vanadate solutions and Fig. 11c. As a result, the action of vanadate as a cathodic inhibitor seems to dominate any effect from buffering. It may be possible that vanadate acting as a buffer does prevent trenching as observed in Fig. 9b, but there is not a corresponding increase in cathodic reactions that would be expected if vanadates were acting strictly as buffers rather than inhibitors. From a purely subjective analysis of Fig. 9b and d, the sample exposed to aerated solution shows less attack. The sample exposed to deaerated solution even shows some white particulate on and near intermetallics, possibly redistributed $\mathrm{Cu}$. Vanadates have been shown to act primarily through the suppression of oxygen reduction kinetics and as a result are not nearly as effective in deaerated solutions, although vanadates are modest anodic inhibitors in both aerated and deaerated solutions. $^{18}$

\section{Conclusions}

1. An inverse relationship exists between reduction in cathodic kinetics and $\mathrm{NaVO}_{3}$ concentration in mildly acidic solutions, where dilute solutions with tetrahedrally coordinated vanadates inhibit cathodic kinetics better than concentrated solutions with octahedrally coordinated vanadates.

2. Tetrahedrally coordinated vanadates inhibit the ability of intermetallic particles and the matrix of Al 2024-T3 to support cathodic reactions in alkaline $\mathrm{NaCl}$ solutions.

3 . Tetrahedrally coordinated vanadates decrease corrosion potential and generally increase pitting potential.

4. The overall reduction of cathodic kinetics on intermetallics and the matrix of Al 2024-T3 in alkaline vanadate solutions shifts the OCP below the potential required to cause $\mathrm{Al}_{2} \mathrm{CuMg}$ breakdown. This may prevent selective $\mathrm{Mg}$ dissolution from $\mathrm{Al}_{2} \mathrm{CuMg}$ and subsequent formation of $\mathrm{Cu}$-enriched clusters capable of supporting rapid cathodic reaction kinetics.

5. Tetrahedral vanadates decrease the incidence of circumferential attack around intermetallic particles.

6. The inhibition of cathodic reactions provided by tetrahedral vanadates dominates any effect from buffering.

\section{Acknowledgments}

Support for portions of this work by Concurrent Technologies Corp., Largo, FL is gratefully acknowledged. The authors also thank Dr. N. Birbilis for intermetallic collection and characterization, Dr. B. N. Padgett for assistance with microelectrochemical cell mea- surement, Dr. T. L. Young for assistance with NMR measurements, and Dr. G. S. Frankel for discussions on experimental approach. article.

Ohio State University assisted in meeting the publication costs of this

\section{References}

1. I. J. Polmear, Light Alloys Metallurgy of the Light Metals, Arnold, London (1995). 2. N. Birbilis and R. G. Buchheit, J. Electrochem. Soc., 155, C117 (2008).

3. N. Birbilis and R. G. Buchheit, J. Electrochem. Soc., 152, B140 (2005).

4. R. G. Buchheit, L. P. Montes, M. A. Martinez, J. Michael, and P. F. Hlava, J. Electrochem. Soc., 146, 4424 (1999).

5. R. G. Buchheit, R. P. Grant, P. F. Hlava, B. Mckenzie, and G. L. Zender, J. Electrochem. Soc., 144, 2621 (1997).

6. R. G. Buchheit, J. Electrochem. Soc., 142, 3994 (1995).

7. T. Suter and R. C. Alkire, J. Electrochem. Soc., 148, B36 (2001).

8. T. H. Muster, A. E. Hughes, and G. E. Thompson, in Corrosion Research Trends, I. S. Wang, Editor, p. 35 (2007).

9. G. O. Ilevbare and J. R. Scully, J. Electrochem. Soc., 148, B196 (2001).

10. P. Leblanc and G. S. Frankel, J. Electrochem. Soc., 149, B239 (2002).

11. G. O. Ilevbare, O. Schneider, R. G. Kelly, and J. R. Scully, J. Electrochem. Soc., 151, B453 (2004).

12. Y. Yoon and R. G. Buchheit, J. Electrochem. Soc., 153, B151 (2006).

13. P. Schmutz and G. S. Frankel, J. Electrochem. Soc., 145, 2295 (1998).

14. G. O. Ilevbare and J. R. Scully, Corrosion (Houston), 57, 134 (2001).

15. M. W. Kendig and R. G. Buchheit, Corrosion (Houston), 59, 379 (2003).

16. R. G. Buchheit, H. Guan, S. Mahajanam, and F. Wong, Prog. Org. Coat., 47, 174 (2003).

17. H. Guan and R. G. Buchheit, Corrosion (Houston), 60, 284 (2004).

18. K. D. Ralston, S. Chrisanti, T. L. Young, and R. G. Buchheit, J. Electrochem. Soc., 155, C350 (2008)

19. R. L. Cook and S. R. Taylor, Corrosion (Houston), 56, 321 (2000).

20. M. Iannuzzi and G. S. Frankel, Corros. Sci., 49, 2371 (2007)

21. M. Iannuzzi, J. Kovac, and G. S. Frankel, Electrochim. Acta, 52, 4032 (2007).

22. M. Iannuzzi, T. Young, and G. S. Frankel, J. Electrochem. Soc., 153, B533 (2006)

23. B. R. W. Hinton, Met. Finish., 89, 55 (1991).

24. M. T. Pope, Heteropoly and Isopoly Oxometalates, Springer-Verlag, Berlin (1983).

25. J. Charles, F. Baes, and R. E. Mesmer, The Hydrolysis of Cations, Robert E. Krieger Publishing Company, Malabar, FL (1986).

26. A. M. Amado, M. Aureliano, P. J. A. Ribeiro-Claro, and J. J. C. Teixeira-Dias, $J$. Raman Spectrosc., 24, 699 (1993).

27. M. Iannuzzi and G. S. Frankel, Corrosion (Houston), 63, 672 (2007).

28. S. P. V. Mahajanam and R. G. Buchheit, Corrosion (Houston), 64, 230 (2008).

29. M. Aureliano and R. M. C. Gandara, J. Inorg. Biochem., 99, 979 (2005).

30. T. J. R. Leclere, A. J. Davenport, and R. C. Newman, Corrosion (Houston), 63, 338 (2007).

31. T. J. R. Leclere and R. C. Newman, J. Electrochem. Soc., 149, B52 (2002).

32. R. M. Leard, in Materials Science and Engineering, The Ohio State University, Columbus, $\mathrm{OH}(2001)$

33. T. Suter and H. Bohni, Electrochim. Acta, 47, 191 (2001).

34. T. Suter and H. Bohni, Electrochim. Acta, 43, 2843 (1998).

35. R. G. Buchheit, M. D. Bode, and G. E. Stoner, Corrosion (Houston), 50, 205 (1994).

36. D. C. Crans, in Metal Ions in Biological Systems Vanadium and Its Role in Life, H. Sigel and A. Sigel, Editors, Marcel Dekker, Inc., New York (1995).

37. J. R. Scully, T. O. Knight, R. G. Buchheit, and D. E. Peebles, Corros. Sci., 35, 185 (1993).

38. R. G. Buchheit, M. A. Martinez, and L. P. Montes, J. Electrochem. Soc., 147, 119 (2000).

39. C.-M. Liao and R. P. Wei, Electrochim. Acta, 45, 881 (1999).

40. R. J. Beynon and J. S. Easterby, Buffer Solutions the Basics, Oxford University Press, Oxford (1996).

41. D. C. Harris, Quantitative Chemical Analysis, W. H. Freeman and Company, New York (2007).

42. D. C. Crans and P. K. Shin, Inorg. Chem., 27, 1797 (1988)

43. D. C. Crans, P. M. Ehde, P. K. Shin, and L. Pettersson, J. Am. Chem. Soc., 113, 3728 (1991) 